\title{
Estimation of the fermentability of dietary fibre in vitro: a European interlaboratory study
}

\author{
BY J-L. BARRY' ${ }^{1}$, C. HOEBLER ${ }^{1}$, G. T. MACFARLANE ${ }^{2}$, S. MACFARLANE ${ }^{2}$, \\ J. C. MATHERS ${ }^{3}$, K. A. REED ${ }^{3}$, P. B. MORTENSEN ${ }^{4}$, I. NORDGAARD ${ }^{4}$, \\ I. R. ROWLAND ${ }^{5}$ AND C. J. RUMNEY ${ }^{5}$ \\ ${ }^{1}$ INRA, Laboratory of Applied Technology and Nutrition, BP 1627, 44316 Nantes cedex 03, France \\ ${ }^{2}$ MRC Dunn Clinical Nutrition Centre, Hills Road, Cambridge CB2 2DH \\ ${ }^{3}$ Department of Biological and Nutritional Science, University of Newcastle upon Tyne, \\ Newcastle upon Tyne NE1 $7 R U$ \\ ${ }^{4}$ Department of Medicine A 2102, Rigshospitalet, DK 2100 Copenhagen, Denmark \\ ${ }^{5}$ BIBRA, Woodmansterne Road, Carshalton SM5 4DS
}

(Received 5 October 1994 - Revised 18 April 1995-Accepted 19 April 1995)

Five European laboratories tested a simple in vitro batch system for dietary fibre fermentation studies. The inoculum was composed of fresh human faeces mixed with a carbonate-phosphate buffer complex supplemented with trace elements and urea. Five dietary fibre sources (cellulose, sugarbeet fibre, soyabean fibre, maize bran and pectin) were used by each laboratory on three occasions to determine pH, residual non-starch polysaccharides (NSP) and short-chain fatty acid production during fermentation. Cellulose and maize bran degradabilities were very low (7.2 (SE 10.8) and 6.2 (SE 9.1) \% respectively after $24 \mathrm{~h}$ ), whereas pectin and soyabean fibre were highly degraded (97.4 (SE 4.4) and 91.1 (SE 3.4) \% respectively after $24 \mathrm{~h}$ ). Sugarbeet fibre exhibited an intermediate level of degradability (59.5 (SE 14.9) \%). Short-chain fatty acid production was closely related to NSP degradation ( $r$ 0.99). Although each variable was ranked similarly by all laboratories, some differences occurred with respect to absolute values. However, the adaptation of donors to the experimental substrates was not an influential factor. Interlaboratory differences could be reduced either by adding less substrate during incubations or using less-diluted inocula. In vitro fermentations with inocula made from human faeces and from rat caecal contents gave similar results. There was a close correspondence between the data obtained in the present experiment and those previously published in in vivo studies in the rat using the same fibres. The in vitro batch system tested during the present study provides a rapid means of obtaining quantitative estimates of the fermentation and the estimation of the energy content of new sources of dietary fibre.

Dietary fibre: In vitro fermentation: Short-chain fatty acids

Studies of the nutritional effects of colonic fermentation of dietary fibres have been widely developed during the past decade, and in vitro fermentation methods have made it possible to predict some of the physiological effects of fibre (McBurney \& Thompson, 1989; Adiotomre et al. 1990). Short-chain fatty acids (SCFA), the main end-products of dietary fibre fermentation, are extensively absorbed and metabolized. As fibre is indigestible in the small intestine, its energy content is conventionally considered to be zero, but this appears to be untrue especially when substantial quantities of fibre are fermented (Livesey, 1990). In addition, many biological effects of SCFA have been reported. Butyrate is metabolized by colonic cells (Roediger, 1982) and could be involved in the protective effect of fibre against colon cancer. SCFA influence carbohydrate and lipid metabolism (Wolever et al. 1992). The specific effect of each SCFA on hindgut motility has recently been reviewed 
Table 1. Summary of conditions used in the literature for batch in vitro fermentations

\begin{tabular}{|c|c|c|c|c|c|}
\hline Reference & $\begin{array}{c}\text { Faeces } \\
\text { concentration } \\
(\mathrm{g} / \mathrm{l})\end{array}$ & $\begin{array}{c}\text { Substrate } \\
\text { amounts } \\
(\mathrm{g} / \mathrm{l})\end{array}$ & Buffer* & $\begin{array}{l}\text { Trace } \\
\text { elements }\end{array}$ & $\begin{array}{l}\text { Duration } \\
\text { (h) }\end{array}$ \\
\hline Vince et al. (1990) & 250 & NA & No & No & 48 \\
\hline $\begin{array}{l}\text { Perman \& Modler (1982), } \\
\text { Flick \& Perman (1989) }\end{array}$ & 125 & 50 & $\mathrm{p}$ & No & 1 \\
\hline Ehle et al. (1982) & NA & NA & No & Yes & 48 \\
\hline Fidgor \& Bianchine (1983) & NA & NA & No & No & 30 \\
\hline McBurney et al. (1985) & $\mathrm{NA}$ & 5 & c & Yes & 24 \\
\hline $\begin{array}{l}\text { Tomlin et al. }(1986) \\
\text { Tomlin \& Read (1988) }\end{array}$ & 50 & 5 & c & No & 21 \\
\hline Slade et al. (1987) & 0.5 to 1.5 & 20 & Yes & Yes & 24 \\
\hline Patil et al. (1987) & 50 & 20 & Not & No & 24 \\
\hline $\begin{array}{l}\text { Rasmussen et al. (1987), } \\
\text { Mortensen et al. (1988) }\end{array}$ & 167 & Up to $\sim 50$ & No & No & 72 \\
\hline Stevens et al. (1988) & 1 to 1.67 & NA & NA & NA & NA \\
\hline Wyatt \& Horn (1988) & 1 & 20 & c & Yes & 168 \\
\hline McBurney \& Thompson (1987) & 13 & 10 & $\mathrm{c} / \mathrm{p}$ & Yes & 24 \\
\hline McBurney et al. (1988) & 60 & 10 & $\mathrm{c} / \mathrm{p}$ & Yes & 24 \\
\hline Mortensen et al. (1989) & 166 & 10 & No & No & 72 \\
\hline Mortensen et al. (1991) & 166 & 10 & $\mathrm{c}$ & No & 24 or 72 \\
\hline McBurney \& Thompson (1989) & 13 & 10 & $\mathbf{c} / \mathbf{p}$ & Yes & 24 \\
\hline Jeraci \& Horvath (1989) & NA & NA & NA & NA & 48 \\
\hline $\begin{array}{l}\text { Barry et al. (1989), Guillon et al. (1992), } \\
\text { Salvador et al. (1993) }\end{array}$ & 250 & 10 & $\mathrm{c} / \mathrm{p}$ & Yes & 24 \\
\hline Adiotomre et al. (1990) & 40 & 10 & $\mathrm{p}$ & Yes & 24 \\
\hline Mortensen \& Nordgaard-Andersen (1993) & 166 & 10 to 30 & $\mathrm{c}$ & No & 24 \\
\hline
\end{tabular}

NA, not available.

* No, no buffer; yes, buffer, composition not specified; p, phosphate buffer; c, carbonate buffer; $\mathrm{c} / \mathrm{p}$, carbonate-phosphate buffer.

$\dagger \mathrm{pH}$ adjusted.

(Cherbut, 1995). Hence there are many reasons why it is important to characterize dietary fibre fermentation with respect to substrate disappearance and, especially, SCFA production.

In vivo fermentation methods allow dietary fibre digestibility to be determined but cannot predict SCFA production during fermentation in humans. It is difficult to collect human colonic contents, and the only published data have been obtained from individuals who experienced sudden death (Cummings et al. 1987). As SCFA are metabolized by colonic cells or the liver, their peripheral blood levels indicate little about their production. Thus, many researchers have developed in vitro systems to characterize fibre fermentation. Continuous or semi-continuous systems (Miller \& Wolin, 1981; Mallet et al. 1983; Edwards et al. 1985; Gibson et al. 1988) are generally used to study the microbial mechanisms involved in fibre fermentation. When the main objective is to study the fermentative fate of various fibres, in vitro batch systems are generally adopted. Table 1, which summarizes the main characteristics of these methods, shows that many elements of the protocol vary from one system to another and that some systems have been modified by the same investigators. The reason why each element of a protocol has been fixed at a precise level is rarely explained. Moreover, there has been no systematic evaluation of these procedures, so the possibility of comparing the results from different centres is limited.

The purpose of the present study was to develop a standardized in vitro method for rapid 
investigation of the fermentation of new fibre sources. Several laboratories tested a standard protocol using a panel of commercial fibre sources, and further experiments were undertaken to determine causes for discrepancies observed in results obtained by the different laboratories.

\section{MATERIALS AND METHODS}

\section{General}

Five European laboratories in Denmark, France and the United Kingdom, all previously involved in in vitro studies of dietary fibre fermentation, undertook these experiments. The laboratories were randomly referenced from I to $\mathrm{V}$ without any relation to the author list. All five tested commercial-fibre fermentation in a ring-test experiment. Specific factors (influence of substrate amounts, donor variability, influence of donor adaptation to fibre and comparison between rat and human inocula) were then studied by at least one of these laboratories.

\section{Fibre sources}

Five commercial sources of dietary fibre were used throughout the experiment. Solka-floc cellulose (crystalline cellulose, grade BW 2030) was provided by Jurgenson and Wettre Ltd (Wokingham, Berks), apple pectin ('slow set' high-methoxyl pectin) by Sanofi BioIndustries (Paris, France), soyabean fibre ('Fibrim 2000', red) by Protein Technologies International (Corby, Northants), maize bran by Honeyville Grain Inc. (Salt Lake City, UT, USA) and sugarbeet fibre ('Betafibre') by British Sugar plc (Peterborough, Cambs). The five fibre sources were analysed for minerals, lipids, starch, total dietary fibre, and crude and soluble proteins (Table 2). The non-starch polysaccharide (NSP) content of these dietary fibre sources is presented in Table 3.

\section{Fermentation procedure}

General schedule. All experiments were conducted in vitro in a batch system. Fermentations were performed in vials using an inoculum made from fresh faeces collected from healthy human volunteers. The volunteers usually ingested a normal diet, presented no digestive disease and had not received antibiotics for at least 3 months. Fermentation variables were measured in vials in which fermentation was stopped at various times.

Inoculum. Faeces were collected in an insulated bottle previously warmed for about $5 \mathrm{~min}$ with hot tap water (approximately $65^{\circ}$ ). To eliminate $\mathrm{O}_{2}$, the bottle was flushed for 5 min with $\mathrm{CO}_{2}$ at a flow of $100 \mathrm{ml} / \mathrm{s}$ and faeces were then collected. When the insulated bottle was received at the laboratory, $\mathrm{CO}_{2}$ was flushed inside. The weight of the faeces was then determined. The inoculum was produced in the insulated bottle by adding five parts of a warmed $\left(37^{\circ}\right)$ nutritive buffer to one part of faeces $(\mathrm{v} / \mathrm{w})$. The nutritive medium was made from a carbonate-phosphate buffer solution containing (g/l): $\mathrm{NaHCO}_{3}$ 9.240, $\mathrm{Na}_{2} \mathrm{HPO}_{4} .12 \mathrm{H}_{2} \mathrm{O} 7 \cdot 125, \mathrm{NaCl} 0 \cdot 470, \mathrm{KCl} \mathrm{0} \cdot 450, \mathrm{Na}_{2} \mathrm{SO}_{4} 0 \cdot 100, \mathrm{CaCl}_{2}$ (anhydrous) 0.055, $\mathrm{MgCl}_{2}$ (anhydrous) 0.047 , urea 0.400 , with added trace elements $(10 \mathrm{ml}$ of the following solution (mg/l) per litre of final solution: $\mathrm{FeSO}_{4} \cdot 7 \mathrm{H}_{2} \mathrm{O} 3680, \mathrm{MnSO}_{4} \cdot 7 \mathrm{H}_{2} \mathrm{O} 1900$, $\mathrm{ZnSO}_{4} .7 \mathrm{H}_{2} \mathrm{O} 440, \mathrm{CoCl}_{2} \cdot 6 \mathrm{H}_{2} \mathrm{O} 120, \mathrm{CuSO}_{4} \cdot 5 \mathrm{H}_{2} \mathrm{O} \quad 98, \mathrm{Mo}_{7}\left(\mathrm{NH}_{4}\right)_{6} \mathrm{O}_{24} \cdot 4 \mathrm{H}_{2} \mathrm{O}$ 17.4) according to Durand et al. (1988). Before use, and during preparation of the inoculum, continuous bubbling of $\mathrm{CO}_{2}$ maintained anaerobiosis and ensured a constant $\mathrm{pH}$. The slurry was mixed using a Stomacher ${ }^{\circledR}$ (Laboratory Blended, Seward Medical, London) apparatus for $2 \mathrm{~min}$ and then filtered through six layers of surgical gauze. The inoculum was maintained in a water bath at $37^{\circ}$ and continuously bubbled with $\mathrm{CO}_{2}$.

Fermentation experiments. Fermentation was conducted in $50 \mathrm{ml}$ polypropylene vials (Becton Dickinson Labware, Lincoln Park, NJ, USA). Except for blanks, $100 \mathrm{mg}$ (drymatter basis) of well-homogenized experimental substrate was weighed into each vial and 
Table 2. Composition of the five dietary fibre sources $(\mathrm{g} / \mathrm{kg} \mathrm{DM})$

\begin{tabular}{lrrrrr}
\hline \hline & \multicolumn{2}{c}{ Maize } & \multicolumn{2}{c}{ Sugarbeet } & Soyabean \\
Fibre source... & Cellulose & bran & Pectin & fibre & fibre \\
\hline DM (g/kg fresh wt) & 926 & 934 & 875 & 892 & 888 \\
Starch* & 0 & 16 & 140 & 1 & 8 \\
TDFt & 1011 & 898 & 818 & 778 & 839 \\
Lipids & 6 & 22 & 4 & 3 & 5 \\
Proteins & 3 & 55 & 34 & 145 & 104 \\
Minerals & 1 & 4 & 13 & 37 & 43 \\
Soluble proteins $\ddagger$ & 3 & 7 & 21 & 9 & 23 \\
\hline \hline
\end{tabular}

TDF, total dietary fibre.

* Determined according to the procedure of Faisant et al. (1995).

+ Determined according to the method of Prosky et al. (1992).

\$ Determined according to Vérité \& Demarquilly (1978).

Table 3. Non-starch polysaccharide content of the dietary fibre sources $(\mathrm{g} / \mathrm{kg} \mathrm{DM})^{*}$ measured by five European laboratories

\begin{tabular}{llrrrr}
\hline \hline Laboratory & Cellulose & $\begin{array}{c}\text { Maize } \\
\text { bran }\end{array}$ & Pectin & $\begin{array}{c}\text { Sugarbeet } \\
\text { fibre }\end{array}$ & $\begin{array}{c}\text { Soyabean } \\
\text { fibre }\end{array}$ \\
\hline I & 820 & 808 & 611 & 721 & 782 \\
II & 1011 & 902 & 677 & 733 & 773 \\
III & 921 & 700 & 723 & 733 & 715 \\
IV & 900 & 783 & 686 & 606 & 682 \\
V & 827 & 801 & 632 & 658 & 646 \\
Mean & 916 & 855 & 644 & 727 & 778 \\
SD & 135 & 66 & 47 & 8 & 6 \\
\hline \hline
\end{tabular}

* Measured by the method of Englyst \& Hudson (1987).

$10 \mathrm{ml}$ inoculum added. Air was displaced by a flow of $\mathrm{O}_{2}$-free $\mathrm{N}_{2}$. After the cap was screwed on, the vial was placed horizontally (time 0 ) in a shaking water bath or an orbital incubator. Fermentation was then performed at $37^{\circ}$ and the results studied at $0,6,10$ and $24 \mathrm{~h}$. Two vials were used for each experimental time and for each substrate. Two blanks were used for each experimental time. At each experimental time, fermentation in corresponding vials was stopped by instantaneous freezing (dry ice).

Sample preparation. Vial contents were homogenized by mechanical mixing (Vortex), the $\mathrm{pH}$ was measured and samples were taken for SCFA determinations. Vials were then shaken mechanically and $40 \mathrm{ml}$ absolute ethanol was added (final concentration $800 \mathrm{ml} / \mathrm{l}$ ). The mixture was thoroughly stirred, kept at $0^{\circ}$ for $30 \mathrm{~min}$ and then analysed or stored at $-20^{\circ}$ until carbohydrate analysis.

\section{Experimental design}

Ring-test procedure. During the ring-test experiment the five laboratories studied fermentation of the five experimental fibres added to the inoculum at $10 \mathrm{~g} / 1$ on three different occasions. In each laboratory the same three volunteers were used each time. The inoculum was made by mixing the individual inocula made from each volunteer in equal amounts. At each experimental time, $\mathrm{pH}$, residual NSP and SCFA production were measured. 
Complementary experiments. The methodology used during the ring test was investigated in four complementary experiments. In each, the standard procedure (with a change in one specific point) was used, and $\mathrm{pH}$ and SCFA production were measured.

(1) Influence of substrate amount. We tested the influence of substrate availability on fermentation in the vials. Three laboratories studied the fermentation of pectin added at 5 , 10 (standard) and $20 \mathrm{~g} / 1$ of the inoculum.

(2) Variability between volunteers with time. Inter- and intrasubject variability were tested by one laboratory. The fermentation of one substrate (soyabean fibre) was studied on three occasions using the individual inocula of four volunteers.

(3) Influence of adaptation. The effect of adaptation of volunteers to the experimental substrates was tested by one laboratory. Two volunteers were used as donors in three states of adaptation: no adaptation or a 2-week adaptation to daily ingestion of $10 \mathrm{~g}$ of either pectin or sugarbeet fibre. On two occasions for each state of adaptation, the fermentation of three substrates (pectin, soyabean fibre, sugarbeet fibre) was studied using the individual inocula of each donor.

(4) Fermentation performed with rat or human inocula. In two laboratories, thirty-six rats were fed ad lib. for 2 weeks with a $100 \mathrm{~g} / \mathrm{kg}$ fibre diet prepared according to Livesey et al. (1995) in which the initial fibre was replaced by a mixture in equal parts of the five fibre sources. The animals were then killed and the caecum contents collected, pooled and used to make the rat inoculum described above. Fermentation was conducted in both laboratories using rat and human inocula (four volunteers, mixed inocula). Cellulose, pectin and soyabean fibre fermentation was studied.

\section{Analysis}

Short-chain fatty acids. In all laboratories, SCFA were quantitated by similar chromatographic methods, each laboratory using its own variant (Holdeman et al. 1977; Jouany, 1982; Schooley et al. 1985; Mathers et al. 1990; Mortensen et al. 1991). Evaluation of procedures in the five laboratories was performed during a preliminary ring test on the same six aqueous standards and nine slurries from a single fermentation study.

Non-starch polysaccharides. After thawing, samples were centrifuged (10 min, $1500 \mathrm{~g})$, supernatant fractions discarded, and $50 \mathrm{ml}$ of absolute ethanol added to the pellet. After stirring, centrifugation was undertaken as indicated above, pellets were dried in a water bath or on a hotplate at about $60^{\circ}$. Dry residues were hydrolysed with $5 \mathrm{ml} 12 \mathrm{M}-\mathrm{H}_{2} \mathrm{SO}_{4}$ $\left(1 \mathrm{~h}, 35^{\circ}\right)$. After addition of $25 \mathrm{ml}$ water, vials were left for $1 \mathrm{~h}$ in a boiling water-bath. After hydrolysis, vials were cooled in tap water. The carbohydrate content was measured by a colorimetric method (Englyst \& Hudson, 1987) using a standard solution (arabinoseglucose-galacturonic acid, 14:7:3 on a molar basis). Participating laboratories were trained in this procedure using the five dietary sources (Table 3 ).

\section{Calculations}

Short-chain fatty acids and residual polysaccharides in slurries. The production $P_{i}$ of each SCFA was calculated as follows for each experimental time:

$$
P_{i}=\left(S_{i}-S_{0}\right)-\left(B_{i}-B_{0}\right)
$$

where $S_{i}$ and $S_{0}$ are SCFA concentration values in vials containing substrates at time $i$ and 0 respectively, and $B_{i}$ and $B_{0}$ are SCFA concentration values for blanks at time $i$ and 0 respectively.

For each experimental time, total SCFA production was calculated as the sum of the individual productions of acetic, propionic, butyric, iso-butyric, valeric and iso-valeric acids. When significant amounts of SCFA were produced, SCFA ratios were calculated for 
acetic (C2), propionic (C3) and butyric (C4) acids and expressed as molar percentages of the sum of the production of these acids.

Calculation of residual NSP was done according to a similar principle, as described by Englyst \& Cummings (1988). NSP loss was calculated as the percentage of initial NSP added that disappeared.

Statistics. All statistics were performed using Stat-View II software (Abacus Concept Inc, CA, USA) on an Apple Macintosh IIci microcomputer. ANOVA followed by the least significant difference (LSD) test were used to test the significance of treatment effects for each variable. As data obtained at different times during fermentation could not be considered to constitute independent variables, ANOVA was not performed using time as a variable.

When several laboratories were involved in a study (ring test, rat $v$. human, influence of fibre amounts), the means of the different laboratories were used as repetitions. The standard deviation within laboratories $\left(\mathrm{SD}_{0}=\right.$ repeatability) was calculated according to Daniéli (1975) as follows:

$$
\mathrm{SD}_{\mathrm{o}}{ }^{2}=\mathrm{VCr} \text {, }
$$

where $\mathrm{VCr}$ is the variance component of the residual. The standard deviation among laboratories $\left(\mathrm{SD}_{\mathbf{L}}=\right.$ reproducibility) was calculated according to Daniéli (1975) as follows:

$$
\mathrm{SD}_{\mathrm{L}}^{2}=\left(\mathrm{VC}_{1}-\mathrm{VCr}\right) / n \text {, }
$$

where $\mathrm{VC}_{\mathrm{l}}$ is the variance component due to laboratories and $n$ the number of occasions.

During variability experiments, $\mathrm{SD}_{\mathrm{s}}$ was the standard deviation due to subjects and $\mathrm{SD}_{0}$ the variability due to the occasions, calculated as described above.

When experiments were conducted in a single laboratory (adaptation, variability), the means of each replication were used as repetitions and SD values were calculated as described above.

\section{RESULTS}

\section{Ring test}

The mean characteristics of inocula at time 0 are shown in Table 4. All variables were similar within each laboratory but varied between laboratories. Differences in $\mathrm{pH}$ were marked even though inocula were prepared with a buffer which should have prevented such variations. Moreover, $\mathrm{pH}$ surprisingly varied with SCFA concentrations.

Variations of $\mathrm{pH}$, NSP degradation and SCFA production during fermentation of the different experimental fibre sources are shown in Figs 1, 2 and 3 respectively. There was little or no $\mathrm{pH}$ decrease with cellulose, soyabean fibre or maize bran, but very rapid decreases with sugarbeet fibre and pectin. NSP degradation remained very low for cellulose and maize bran but was rapid and high with pectin and soyabean fibre. SCFA production presented similar changes, and there was a very close relationship between NSP breakdown and SCFA production (Fig. 4). The proportions of acetic, propionic and butyric acids are shown in Fig. 5. Significant differences were observed for acetic (pectin $v$. soyabean fibre; $P=0.0053$ at $24 \mathrm{~h}$ ) and propionic (soyabean and sugarbeet fibre $v$. pectin; $P=0.0001$ at $24 \mathrm{~h}$ ) acids. There were no significant differences in butyric acid proportions between substrates.

Individual laboratory data concerning $\mathrm{pH}$, NSP degradation and SCFA production are given in Tables 5, 6 and 7 respectively. Differences between laboratories were meaningful and highly significant for all these variables. High measurement repeatability, i.e. low intralaboratory variability, was observed for $\mathrm{pH}$ and SCFA production, whereas interlaboratory reproducibility tended to be lower.

Unusual NSP degradation values were sometimes noted, and some negative data were 
Table 4. Characteristics of inocula used by five laboratories in a ring test of in vitro fermentation of the dietary fibre sources

(Mean values and standard deviations for three experiments from each laboratory)

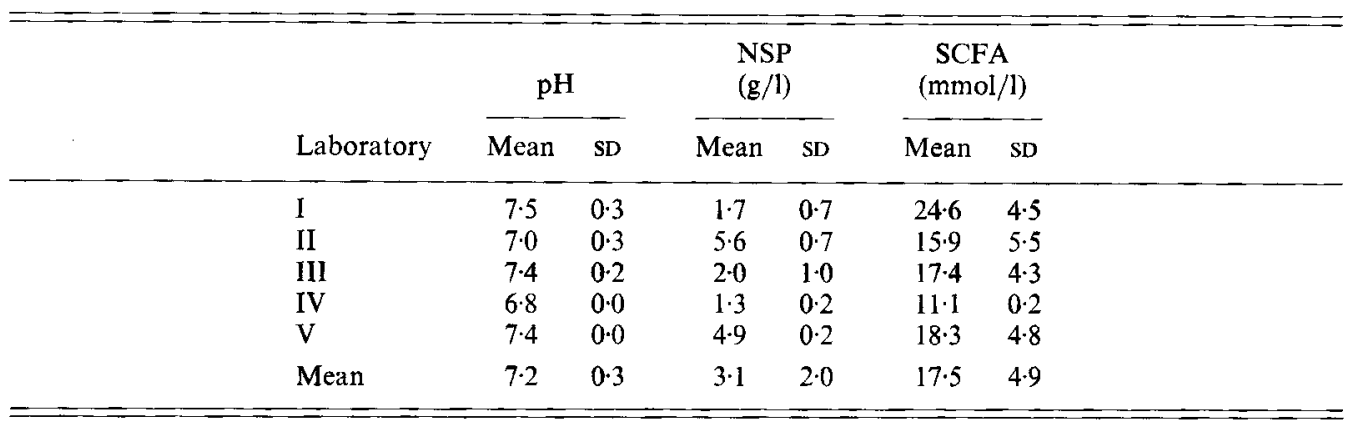

SCFA, short-chain fatty acids.

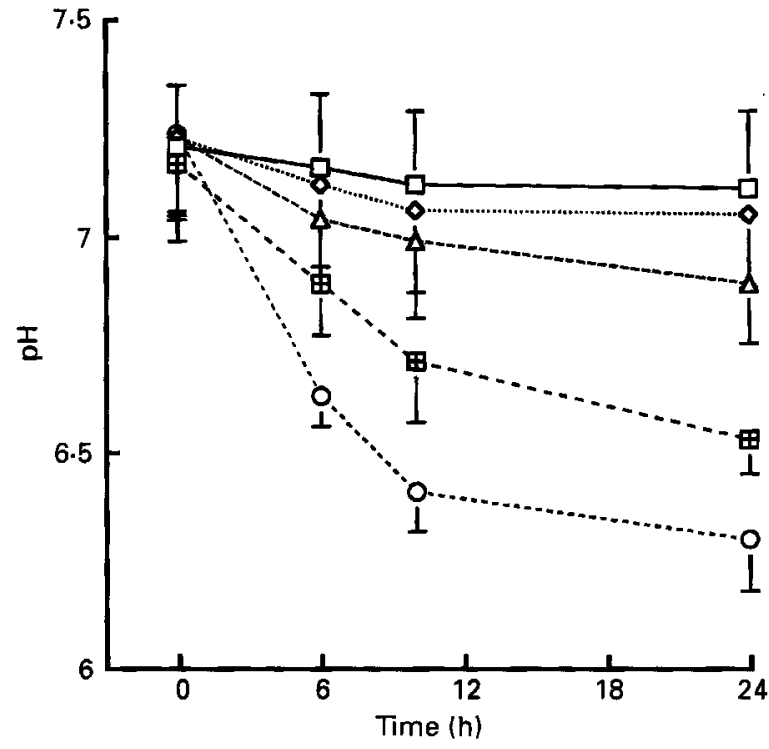

Fig. 1. Changes in $\mathrm{pH}$ over time during the in vitro fermentation of cellulose $(-\square-)$, soyabean fibre $(\cdots \diamond \cdots)$, pectin $\left(--\mathrm{O}_{--}\right)$, maize bran $\left(--\triangle_{--)}\right.$and sugarbeet fibre $(--\mathbb{D}--)$ using human faecal inocula. Values are means for five laboratories, each of which made the measurements on three occasions; standard errors of the means are shown by vertical bars.

observed, especially with poorly degradable substrates. Conversely, very high degradation rates were sometimes observed for cellulose, although corresponding SCFA production was not significant. Moreover, intralaboratory reproducibility was much lower for carbohydrate determination than for $\mathrm{pH}$ and SCFA production. Despite interlaboratory differences for quantitative data, there was good agreement in ranking the degradation of most of the experimental substrates. Pectin was always found to be highly degraded, 


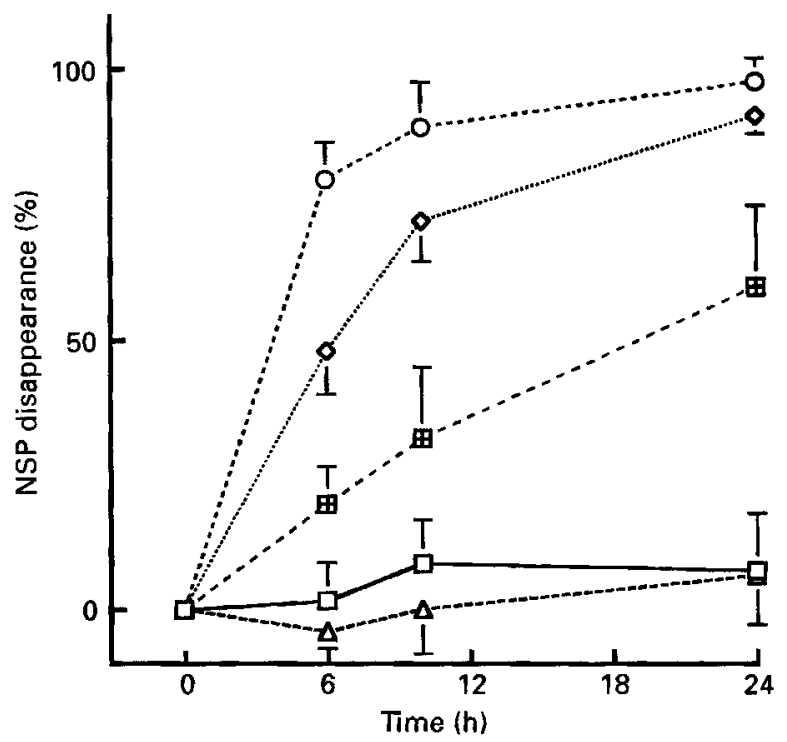

Fig. 2. Disappearance of NSP during the in vitro fermentation of cellulose $(-\square-)$, soyabean fibre ( $\cdots \diamond \cdots)$, pectin $\left(--\mathrm{O}_{--}\right)$, maize bran $\left(--\Delta_{--}\right)$and sugarbeet fibre $\left(--\mathbb{\theta}_{--}\right)$using human faecal inocula. Values are means for five laboratories, each of which made the measurements on three occasions; standard errors of the means are shown by vertical bars.

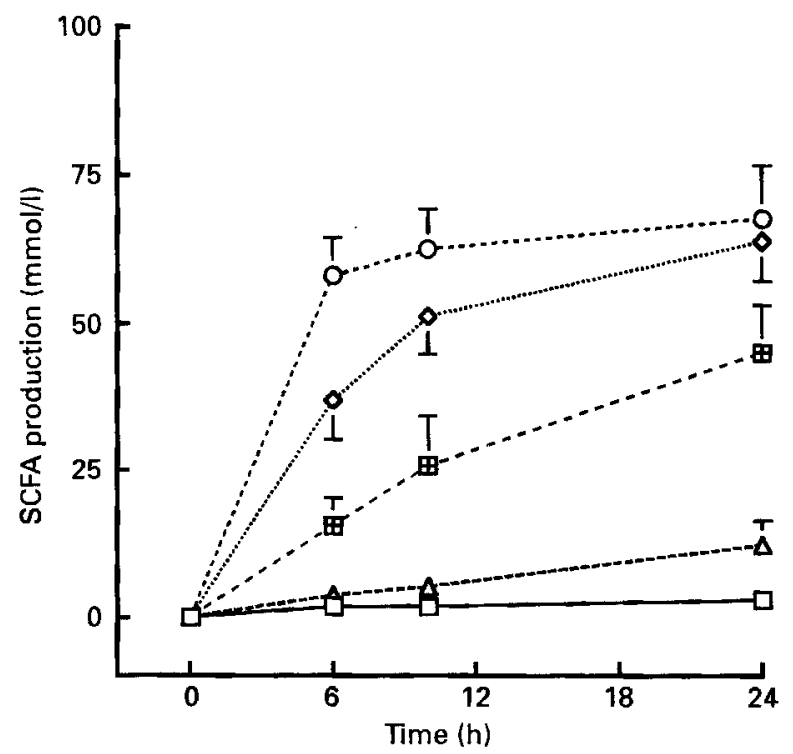

Fig. 3. Production of short-chain fatty acids (SCFA; mmol/l) during the in vitro fermentation of cellulose $(-\square-)$, soyabean fibre $(\cdots \diamond \cdots)$, pectin $\left(-O^{--}\right)$, maize bran $\left(-\Delta^{--}\right)$and sugarbeet fibre $\left(-\uplus^{--}\right)$using human faecal inocula. Values are means for five laboratories, each of which made the measurements on three occasions; standard errors of the means are shown by vertical bars.

followed immediately by soyabean fibre and sugarbeet fibre. However, there was a discrepancy concerning sugarbeet fibre, which two laboratories found to be slightly degraded and the three others quite extensively degraded. Cellulose and maize bran were not, or only slightly, fermented in all laboratories. 


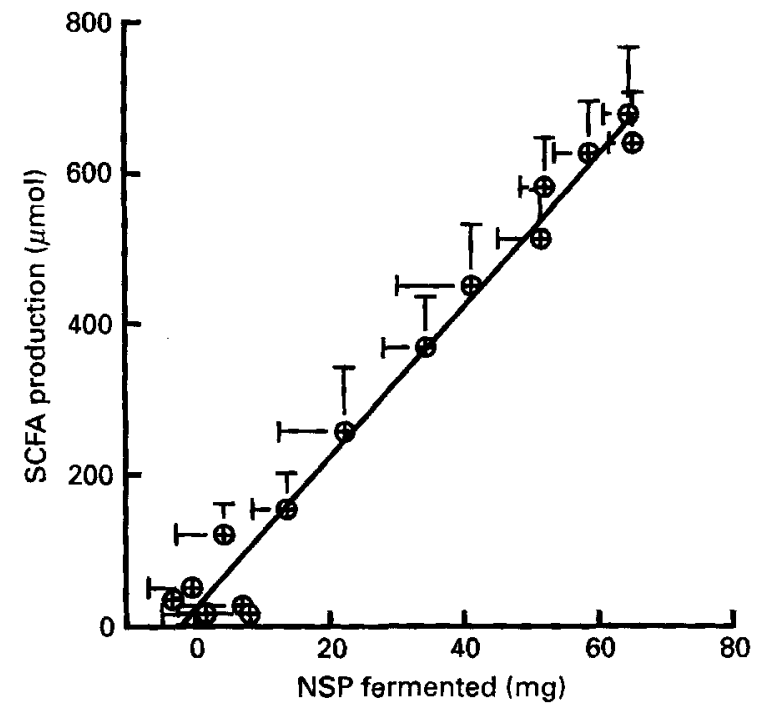

Fig. 4. Relationship between NSP degradation (mg) and short-chain fatty acid (SCFA) production ( $\mu$ mol) in in vitro fermentations of dietary fibre sources. The line is described by the equation $y=9 \cdot 93 x+20 \cdot 8(r 0.988)$. Values are means for five laboratories, each of which made the measurements on three occasions; standard errors of the means are indicated by vertical and horizontal bars.

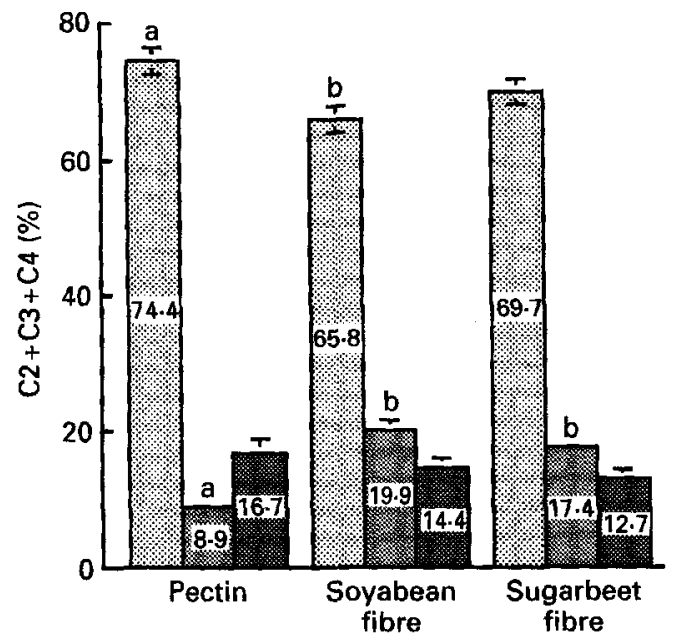

Fig. 5. Molar proportions (\%) of the short-chain fatty acids acetate (C2, 8 ), propionate (C3, 关) and butyrate (C4, produced during the in vitro fermentation of pectin, soyabean fibre and sugarbeet fibre using human faecal inocula. Values are means for five laboratories, each of which made the measurements on three occasions; standard errors of the mean are shown by vertical bars. ${ }^{\text {s. b }}$ Columns within a short-chain fatty acid category bearing different letters were significantly different $(P<0 \cdot 05)$.

SCFA production, despite significant interlaboratory differences, was rated in the same way by all laboratories except $\mathrm{V}$ which found slightly higher relative figures for soyabean fibre. SCFA molar ratios (Table 8) differed significantly between laboratories. However, despite certain discrepancies (mainly with acetate), the ranking of each SCFA according to the origin of the dietary source gave generally good agreement for all laboratories. 
Table 5. Changes in the $p H^{*}$ of inocula observed by five laboratories during a ring test of in vitro fermentation of the dietary fibre sources

\begin{tabular}{|c|c|c|c|c|c|c|c|c|c|c|}
\hline \multirow[b]{2}{*}{ Fibre source } & \multirow{2}{*}{$\begin{array}{c}\text { Time } \\
\text { (h) }\end{array}$} & \multicolumn{5}{|c|}{ Laboratory } & \multirow[b]{2}{*}{ Mean } & \multirow[b]{2}{*}{$\mathrm{SD}_{\mathrm{L}}$} & \multirow[b]{2}{*}{$\mathrm{SD}_{\mathrm{o}}$} & \multirow[b]{2}{*}{ LSD } \\
\hline & & I & II & III & IV & V & & & & \\
\hline \multirow[t]{3}{*}{ Pectin } & 6 & -0.87 & -0.20 & $-1 \cdot 02$ & $-0 \cdot 20$ & -0.66 & -0.59 & $0 \cdot 37$ & 0.12 & 0.21 \\
\hline & 10 & $-1 \cdot 05$ & -0.35 & $-1 \cdot 37$ & -0.42 & -0.89 & -0.82 & 0.41 & $0 \cdot 24$ & 0.44 \\
\hline & 24 & -1.02 & -0.53 & -1.57 & -0.55 & -0.99 & -0.93 & 0.42 & $0 \cdot 15$ & $0 \cdot 28$ \\
\hline \multirow[t]{3}{*}{ Sugarbeet fibre } & 6 & -0.51 & $-0 \cdot 10$ & -0.50 & -0.07 & $-0 \cdot 21$ & $-0 \cdot 28$ & 0.20 & $0 \cdot 12$ & $0 \cdot 22$ \\
\hline & 10 & $-0 \cdot 80$ & -0.17 & -0.92 & -0.15 & -0.25 & -0.46 & 0.36 & $0 \cdot 14$ & 0.25 \\
\hline & 24 & -1.00 & -0.23 & -0.97 & -0.32 & -0.68 & -0.64 & 0.34 & $0 \cdot 19$ & 0.35 \\
\hline \multirow[t]{3}{*}{ Soyabean fibre } & 6 & 0.00 & -0.02 & -0.48 & $-0 \cdot 10$ & 0.02 & $-0 \cdot 12$ & 0.20 & $0 \cdot 12$ & 0.22 \\
\hline & 10 & -0.03 & -0.08 & -0.63 & -0.08 & -0.03 & -0.17 & $0 \cdot 24$ & 0.17 & 0.31 \\
\hline & 24 & -0.11 & -0.08 & -0.59 & -0.05 & -0.08 & -0.18 & $0 \cdot 18$ & $0 \cdot 26$ & 0.47 \\
\hline \multirow[t]{3}{*}{ Maize bran } & 6 & $-0 \cdot 10$ & -0.02 & -0.54 & -0.13 & -0.14 & -0.19 & $0 \cdot 20$ & 0.08 & 0.14 \\
\hline & 10 & -0.09 & -0.08 & -0.67 & -0.20 & -0.18 & -0.24 & 0.23 & 0.17 & 0.31 \\
\hline & 24 & -0.38 & $-0 \cdot 12$ & -0.73 & -0.23 & -0.25 & -0.34 & $0 \cdot 16$ & $0 \cdot 30$ & 0.55 \\
\hline \multirow[t]{3}{*}{ Solka-floc cellulose } & 6 & 0.08 & $-0 \cdot 13$ & -0.24 & -0.05 & 0.07 & -0.05 & 0.06 & 0.21 & 0.38 \\
\hline & 10 & 0.07 & -0.23 & -0.34 & -0.03 & 0.08 & -0.09 & 0.13 & 0.22 & 0.41 \\
\hline & 24 & 0.06 & -0.27 & -0.32 & -0.05 & 0.08 & $-0 \cdot 10$ & 0.13 & $0 \cdot 23$ & 0.43 \\
\hline
\end{tabular}

$\mathrm{SD}_{\mathbf{L}}$, standard deviation among laboratories; $\mathrm{SD}_{0}$, standard deviation among occasions; LSD, least significant difference $(P<0.05)$.

* Variations of $\mathrm{pH}$ are expressed as the difference between $\mathrm{pH}$ at experimental times and that at zero time.

Table 6. Percentage fibre degradability values obtained by five laboratories in a ring test of in vitro fermentation of the dietary fibre sources

\begin{tabular}{|c|c|c|c|c|c|c|c|c|c|c|}
\hline \multirow[b]{2}{*}{ Fibre source } & \multirow{2}{*}{$\begin{array}{c}\text { Time } \\
\text { (h) }\end{array}$} & \multicolumn{5}{|c|}{ Laboratory } & \multirow[b]{2}{*}{ Mean } & \multirow[b]{2}{*}{$\mathbf{S D}_{\mathrm{L}}$} & \multirow[b]{2}{*}{$\mathbf{S D}_{0}$} & \multirow[b]{2}{*}{ LSD } \\
\hline & & I & II & III & IV & $\mathrm{V}$ & & & & \\
\hline \multirow{3}{*}{ Pectin } & 6 & $104 \cdot 7$ & $66 \cdot 8$ & $70 \cdot 9$ & $83 \cdot 0$ & $71 \cdot 3$ & $79 \cdot 3$ & $13 \cdot 3$ & $13 \cdot 6$ & $24 \cdot 7$ \\
\hline & 10 & 111.9 & 85.8 & 73.8 & $104 \cdot 6$ & $69 \cdot 0$ & $89 \cdot 0$ & $16 \cdot 3$ & $16 \cdot 0$ & $29 \cdot 2$ \\
\hline & 24 & 104.9 & $93 \cdot 2$ & $98 \cdot 6$ & $107 \cdot 3$ & 83.0 & $97 \cdot 4$ & $7 \cdot 5$ & $10 \cdot 9$ & $19 \cdot 8$ \\
\hline \multirow[t]{3}{*}{ Sugarbeet fibre } & 6 & $36 \cdot 9$ & $-2 \cdot 3$ & $29 \cdot 2$ & 11.7 & $22 \cdot 5$ & $19 \cdot 6$ & $14 \cdot 4$ & $9 \cdot 3$ & $16 \cdot 9$ \\
\hline & 10 & $69 \cdot 6$ & 0.8 & 56.6 & $20 \cdot 7$ & $11 \cdot 1$ & $31 \cdot 8$ & $28 \cdot 7$ & 13.8 & $25 \cdot 1$ \\
\hline & 24 & $97 \cdot 8$ & $14 \cdot 4$ & $77 \cdot 2$ & $37 \cdot 6$ & $70 \cdot 7$ & $59 \cdot 5$ & $31 \cdot 5$ & $18 \cdot 3$ & $33 \cdot 4$ \\
\hline \multirow[t]{3}{*}{ Soyabean fibre } & 6 & $69 \cdot 0$ & $32 \cdot 6$ & $58 \cdot 0$ & $26 \cdot 2$ & $53 \cdot 6$ & 47.9 & $17 \cdot 2$ & $8 \cdot 5$ & $15 \cdot 5$ \\
\hline & 10 & $95 \cdot 0$ & $55 \cdot 0$ & $80 \cdot 1$ & 56.0 & $72 \cdot 0$ & $71 \cdot 6$ & 14.5 & $14 \cdot 8$ & $26 \cdot 9$ \\
\hline & 24 & $98 \cdot 3$ & $80 \cdot 1$ & $98 \cdot 2$ & $88 \cdot 6$ & $90 \cdot 1$ & $91 \cdot 1$ & $2 \cdot 4$ & $12 \cdot 5$ & $22 \cdot 7$ \\
\hline \multirow[t]{3}{*}{ Maize bran } & 6 & $4 \cdot 3$ & $-2 \cdot 2$ & $-5 \cdot 2$ & $-2 \cdot 0$ & -15.4 & $-4 \cdot 1$ & $1 \cdot 2$ & $12 \cdot 3$ & $22 \cdot 3$ \\
\hline & 10 & $20 \cdot 8$ & $-4 \cdot 2$ & $11 \cdot 6$ & $-0 \cdot 1$ & -27.5 & 0.1 & 158 & $16 \cdot 1$ & $29 \cdot 4$ \\
\hline & 24 & $27 \cdot 2$ & $-4 \cdot 6$ & 250 & $4 \cdot 3$ & $-21 \cdot 0$ & $6 \cdot 2$ & 15.8 & $22 \cdot 0$ & $40 \cdot 1$ \\
\hline \multirow[t]{3}{*}{ Solka-floc cellulose } & 6 & $-5 \cdot 0$ & 1.0 & $-8 \cdot 3$ & $29 \cdot 4$ & $-9 \cdot 3$ & 1.6 & $11 \cdot 5$ & $19 \cdot 4$ & $35 \cdot 3$ \\
\hline & 10 & $-4 \cdot 4$ & $7 \cdot 6$ & $10 \cdot 6$ & $37 \cdot 9$ & $-9 \cdot 0$ & $8 \cdot 5$ & $14 \cdot 2$ & $20 \cdot 0$ & 36.5 \\
\hline & 24 & -14.9 & $10 \cdot 0$ & $7 \cdot 3$ & $45 \cdot 3$ & -11.9 & $7 \cdot 2$ & 21.8 & $17 \cdot 4$ & $31 \cdot 6$ \\
\hline
\end{tabular}

$\mathbf{S D}_{L}$, standard deviation among laboratories; $\mathbf{S D}_{0}$, standard deviation among occasions; LSD, least significant difference $(P<0.05)$.

\section{Complementary experiments}

Influence of substrate amount. During the course of fermentation, $\mathrm{pH}$ ranged between $6.67-6.97,6.49-6.98$ and 5.40-6.88 when fibre was added at levels of 5, 10 and $20 \mathrm{~g} / \mathrm{l}$ respectively. Although $\mathrm{pH}$ values as low as 5 have already been reported, $\mathrm{pH}$ values with 
Table 7. Values for short-chain fatty acid production (mmol/l) obtained by five laboratories during a ring test of in vitro fermentation of the dietary fibre sources

\begin{tabular}{|c|c|c|c|c|c|c|c|c|c|c|}
\hline \multirow[b]{2}{*}{ Fibre source } & \multirow{2}{*}{$\begin{array}{c}\text { Time } \\
\text { (h) }\end{array}$} & \multicolumn{5}{|c|}{ Laboratory } & \multirow[b]{2}{*}{ Mean } & \multirow[b]{2}{*}{$\mathrm{SD}_{\mathrm{L}}$} & \multirow[b]{2}{*}{$\mathrm{SD}_{\mathrm{o}}$} & \multirow[b]{2}{*}{ LSD } \\
\hline & & I & II & III & IV & V & & & & \\
\hline \multirow[t]{3}{*}{ Pectin } & 6 & $76 \cdot 4$ & $67 \cdot 4$ & $54 \cdot 1$ & $39 \cdot 5$ & $52 \cdot 5$ & $58 \cdot 0$ & $12 \cdot 7$ & $11 \cdot 2$ & 0.2 \\
\hline & 10 & $70 \cdot 5$ & $82 \cdot 7$ & $57 \cdot 2$ & $44 \cdot 5$ & $55 \cdot 2$ & $62 \cdot 0$ & $14 \cdot 4$ & $6 \cdot 3$ & 0.4 \\
\hline & 24 & $76 \cdot 1$ & $96 \cdot 6$ & $67 \cdot 3$ & $46 \cdot 4$ & $52 \cdot 1$ & $67 \cdot 7$ & $19 \cdot 7$ & $5 \cdot 9$ & $0 \cdot 3$ \\
\hline \multirow[t]{3}{*}{ Sugarbeet fibre } & 6 & $32 \cdot 1$ & $10 \cdot 1$ & $19 \cdot 4$ & 6.9 & $8 \cdot 3$ & 15.4 & $10 \cdot 1$ & $5 \cdot 1$ & $9 \cdot 3$ \\
\hline & 10 & $53 \cdot 7$ & $17 \cdot 9$ & 36.9 & 60 & $13 \cdot 8$ & $25 \cdot 7$ & $18 \cdot 4$ & $8 \cdot 9$ & $16 \cdot 2$ \\
\hline & 24 & $72 \cdot 2$ & $30 \cdot 0$ & 53.9 & $29 \cdot 1$ & $38 \cdot 4$ & $44 \cdot 7$ & $17 \cdot 4$ & $9 \cdot 0$ & 16.4 \\
\hline \multirow[t]{3}{*}{ Soyabean fibre } & 6 & $59 \cdot 7$ & $33 \cdot 1$ & $35 \cdot 1$ & $18-3$ & $37 \cdot 5$ & $36 \cdot 7$ & 14.9 & 6.7 & $12 \cdot 5$ \\
\hline & 10 & $69 \cdot 5$ & $52 \cdot 1$ & $50 \cdot 1$ & $29 \cdot 4$ & $54-8$ & $51 \cdot 2$ & $14 \cdot 2$ & $7 \cdot 1$ & $13 \cdot 2$ \\
\hline & 24 & $78 \cdot 8$ & $75 \cdot 2$ & 63.8 & $41 \cdot 2$ & $59 \cdot 2$ & $63 \cdot 6$ & $13 \cdot 1$ & $13 \cdot 4$ & 24.8 \\
\hline \multirow[t]{3}{*}{ Maize bran } & 6 & 4.9 & $3 \cdot 6$ & $5 \cdot 3$ & $1 \cdot 0$ & $4 \cdot 5$ & 3.9 & $1 \cdot 4$ & $3 \cdot 6$ & $6 \cdot 6$ \\
\hline & 10 & 6.8 & $4 \cdot 4$ & $11 \cdot 0$ & $4 \cdot 5$ & $-1 \cdot 5$ & $5 \cdot 0$ & $3 \cdot 5$ & $4 \cdot 9$ & $9 \cdot 0$ \\
\hline & 24 & $25 \cdot 7$ & 8.0 & $16 \cdot 6$ & $6 \cdot 8$ & $3 \cdot 3$ & $12 \cdot 1$ & 8.0 & $7 \cdot 8$ & $14 \cdot 1$ \\
\hline \multirow[t]{3}{*}{ Solka-floc cellulose } & 6 & $2 \cdot 4$ & $1 \cdot 0$ & 1.9 & $0-1$ & $3 \cdot 0$ & 1.7 & $1 \cdot 1$ & $2 \cdot 6$ & $4 \cdot 8$ \\
\hline & 10 & $3 \cdot 5$ & 1.9 & $2 \cdot 1$ & 1.9 & $-1 \cdot 0$ & 1.7 & 0.7 & $2 \cdot 7$ & $5 \cdot 1$ \\
\hline & 24 & $6 \cdot 9$ & $5 \cdot 2$ & $2 \cdot 4$ & 0.7 & -0.3 & $3 \cdot 0$ & $2 \cdot 6$ & $2 \cdot 1$ & 4.0 \\
\hline
\end{tabular}

$\mathrm{SD}_{1}$, standard deviation among laboratories; $\mathrm{SD}_{\mathbf{0}}$, standard deviation among occasions; LSD, least significant difference $(P<0.05)$.

fibres added at the $20 \mathrm{~g} / \mathrm{l}$ level were out of the generally accepted 6-7 range. Increased amounts of fibre led to greater SCFA production (Fig. 6). Additional SCFA production was low when amounts increased from 10 to $20 \mathrm{~g} / 1$, especially for the first fermentation periods. Increasing the amount of fibre led to a reduction of fibre degradation rate. Regardless of the fermentation stage, there were no significant modifications of the SCFA ratio between the different fibre levels.

Variability between volunteers with time. Variations in SCFA production and ratios between donors on a day-to-day basis are given in Table 9. Although there were some interdonor differences, only a few, namely those concerning the proportion of propionate produced at 6 and $10 \mathrm{~h}$, were significant. The results showed that variability for each donor from one day to the next was greater than the variations observed between donors indicating that the intra- and interdonor variability are very much in the same range.

Influence of adaptation. The influence of donor adaptation on SCFA production is shown in Table 10. Irrespective of substrate tested, the type of adaptation and the time of fermentation, no influence of adaptation on fermentation was found. The relative proportions of SCFA (not reported) were not influenced by donor adaptation.

Rat v. human inocula. Data from the experiment conducted with rat caecal inocula $v$. human inocula are presented in Table 11. Results for all variables were similar regardless of the nature of the inoculum. No statistically significant differences were found.

\section{DISCUSSION}

In vitro fermentation of five dietary fibre sources was studied during a ring test by five groups of investigators using the same protocols on three different occasions. A complex nutritive solution, buffered with carbonate and phosphate and supplemented with trace elements and urea as a $\mathrm{N}$ source, was used. Carbonate is a physiological component secreted within the digestive tract, and bacteria need trace elements and $\mathrm{N}$ for growth. The high degradation obtained with several fibres clearly indicated that significant bacterial 
Table 8. Short-chain fatty acid profiles ( $\mathrm{mol} / 100 \mathrm{~mol}$ ) observed by five laboratories in a ring test of in vitro fermentation of the dietary fibre sources

\begin{tabular}{|c|c|c|c|c|c|c|c|c|c|c|c|}
\hline \multirow[b]{2}{*}{ Fibre } & \multirow{2}{*}{$\begin{array}{c}\text { Time } \\
\text { (h) }\end{array}$} & & \multicolumn{5}{|c|}{ Laboratory } & \multirow[b]{2}{*}{ Mean } & \multirow[b]{2}{*}{$\mathbf{S D}_{\mathbf{L}}$} & \multirow[b]{2}{*}{$\mathrm{SD}_{0}$} & \multirow[b]{2}{*}{ LSD } \\
\hline & & & I & II & III & IV & $\mathrm{V}$ & & & & \\
\hline \multirow[t]{9}{*}{ Pectin } & 6 & $\mathrm{C} 2$ & $77 \cdot 3$ & $86 \cdot 4$ & $80 \cdot 0$ & $83 \cdot 2$ & $75 \cdot 0$ & $80-4$ & $2 \cdot 8$ & $6 \cdot 2$ & $11 \cdot 3$ \\
\hline & & C3 & 11.4 & 8.9 & $8 \cdot 6$ & 30 & $8 \cdot 1$ & $8 \cdot 0$ & $3 \cdot 0$ & $1 \cdot 2$ & $2 \cdot 1$ \\
\hline & & $\mathrm{C} 4$ & $11 \cdot 3$ & 47 & $11 \cdot 3$ & 13.8 & 16.9 & $11 \cdot 6$ & 3.0 & $5 \cdot 8$ & $10 \cdot 5$ \\
\hline & 10 & $\mathrm{C} 2$ & $75 \cdot 2$ & $84 \cdot 5$ & $75 \cdot 6$ & $74 \cdot 4$ & 71.0 & $76 \cdot 1$ & $4 \cdot 2$ & 4.8 & $8 \cdot 7$ \\
\hline & & $\mathrm{C} 3$ & $13 \cdot 4$ & 10.4 & $9 \cdot 6$ & 6.5 & 8.0 & $9 \cdot 6$ & $2 \cdot 4$ & $2 \cdot 0$ & 3.6 \\
\hline & & $\mathrm{C} 4$ & 11.4 & $4 \cdot 2$ & 14.8 & $19 \cdot 2$ & $21 \cdot 1$ & $14 \cdot 1$ & $5 \cdot 8$ & $4 \cdot 6$ & 8.5 \\
\hline & 24 & $\mathrm{C} 2$ & $71 \cdot 1$ & $81 \cdot 9$ & $77 \cdot 8$ & $76 \cdot 6$ & $64 \cdot 6$ & 74.4 & $6 \cdot 1$ & $5 \cdot 1$ & $9 \cdot 3$ \\
\hline & & $\mathrm{C} 3$ & 13.5 & 9-6 & $10 \cdot 6$ & $2 \cdot 2$ & $8 \cdot 8$ & 8.9 & $4 \cdot 1$ & $1 \cdot 4$ & $2 \cdot 6$ \\
\hline & & $\mathrm{C} 4$ & $15 \cdot 5$ & $8 \cdot 5$ & 11.6 & $21 \cdot 1$ & $26 \cdot 7$ & $16 \cdot 7$ & 6.7 & 4.9 & $9 \cdot 0$ \\
\hline \multirow[t]{9}{*}{ Sugarbeet fibre } & 6 & $\mathrm{C} 2$ & $71 \cdot 0$ & $92 \cdot 1$ & $83 \cdot 8$ & $65 \cdot 0$ & $80 \cdot 6$ & $78 \cdot 5$ & $9 \cdot 3$ & $9 \cdot 2$ & $16 \cdot 7$ \\
\hline & & $\mathrm{C3}$ & $22 \cdot 0$ & $7 \cdot 3$ & $10 \cdot 6$ & $13 \cdot 4$ & $11 \cdot 1$ & $12 \cdot 9$ & $3 \cdot 4$ & $7 \cdot 6$ & $13 \cdot 8$ \\
\hline & & $\mathrm{C} 4$ & $7 \cdot 0$ & 0.6 & $5 \cdot 6$ & $21 \cdot 5$ & $8 \cdot 3$ & $8 \cdot 6$ & $7 \cdot 4$ & $4 \cdot 4$ & $8 \cdot 1$ \\
\hline & 10 & $\mathrm{C} 2$ & $71 \cdot 6$ & 92.5 & $70 \cdot 2$ & $65 \cdot 9$ & $75 \cdot 5$ & $75 \cdot 2$ & $9 \cdot 5$ & $6 \cdot 5$ & $13 \cdot 5$ \\
\hline & & $\mathrm{C3}$ & $20 \cdot 6$ & $6 \cdot 8$ & $16 \cdot 0$ & $13 \cdot 4$ & 13.8 & $14 \cdot 1$ & $4 \cdot 1$ & $5 \cdot 4$ & $9 \cdot 9$ \\
\hline & & $\mathrm{C4}$ & $7 \cdot 8$ & $0 \cdot 7$ & 13.8 & $20 \cdot 7$ & $10 \cdot 8$ & $10 \cdot 8$ & 6.8 & $2 \cdot 9$ & $5 \cdot 3$ \\
\hline & 24 & $\mathrm{C} 2$ & $68 \cdot 6$ & $82 \cdot 1$ & $66 \cdot 4$ & $65 \cdot 4$ & $65 \cdot 9$ & $69 \cdot 7$ & 6.8 & $3 \cdot 3$ & $6 \cdot 0$ \\
\hline & & $\mathrm{C} 3$ & $20 \cdot 6$ & $14 \cdot 2$ & $17 \cdot 7$ & $19 \cdot 1$ & $16 \cdot 7$ & $17 \cdot 7$ & $2 \cdot 2$ & $2 \cdot 5$ & $4 \cdot 5$ \\
\hline & & $\mathrm{C4}$ & 10.8 & 3.7 & 160 & $15 \cdot 5$ & $37 \cdot 4$ & $12 \cdot 7$ & 54 & $2 \cdot 6$ & $4 \cdot 7$ \\
\hline \multirow[t]{9}{*}{ Soyabean fibre } & 6 & $\mathrm{C} 2$ & $60 \cdot 1$ & $83 \cdot 2$ & $73 \cdot 5$ & $73 \cdot 7$ & 64.6 & $71 \cdot 0$ & $9 \cdot 3$ & $4 \cdot 1$ & 7.6 \\
\hline & & C3 & 28.0 & 13.9 & 13.4 & 14.9 & $22 \cdot 7$ & $18 \cdot 5$ & 9.9 & $9 \cdot 4$ & $17 \cdot 4$ \\
\hline & & $\mathrm{C} 4$ & 11.9 & 3.0 & $13 \cdot 1$ & 11.5 & 12.8 & $10 \cdot 4$ & $4 \cdot 2$ & $5 \cdot 7$ & 10.5 \\
\hline & 10 & $\mathrm{C} 2$ & 61.6 & $81 \cdot 3$ & 66.5 & $65 \cdot 6$ & 64.9 & $68 \cdot 0$ & 7.5 & $4 \cdot 1$ & 7.6 \\
\hline & & C3 & $27 \cdot 3$ & $14 \cdot 5$ & 17.4 & 23.9 & $21 \cdot 4$ & $20 \cdot 9$ & $5 \cdot 0$ & $2 \cdot 6$ & 49 \\
\hline & & $\mathrm{C} 4$ & $11 \cdot 1$ & $4 \cdot 2$ & $16 \cdot 1$ & $10 \cdot 6$ & $13 \cdot 7$ & $11 \cdot 1$ & $4 \cdot 4$ & $2 \cdot 2$ & $4 \cdot 1$ \\
\hline & 24 & C2 & $58 \cdot 0$ & $75 \cdot 2$ & $66 \cdot 2$ & $65 \cdot 4$ & $61 \cdot 0$ & $65 \cdot 2$ & 6.4 & $3 \cdot 8$ & 7.0 \\
\hline & & C3 & $28 \cdot 4$ & $19 \cdot 1$ & $17 \cdot 4$ & $19 \cdot 1$ & $21 \cdot 1$ & $21 \cdot 0$ & $5 \cdot 5$ & 3.0 & 5.5 \\
\hline & & $\mathrm{C} 4$ & $13 \cdot 6$ & $5 \cdot 8$ & $16 \cdot 4$ & $15 \cdot 5$ & 17.9 & $13 \cdot 8$ & 4.9 & $3 \cdot 3$ & $6 \cdot 1$ \\
\hline
\end{tabular}

$\mathrm{SD}_{\mathrm{L}}$, standard deviation among laboratories; $\mathrm{SD}_{\mathrm{O}}$, standard deviation among occasions; $\mathrm{LSD}$, least significant difference $(P<0.05)$; 2 , acetate; $\mathrm{C} 3$, propionate; $\mathrm{C} 4$, butyrate.

activity was present in the slurries throughout the $24 \mathrm{~h}$ experiments. During preparation of faecal slurries, homogenates were filtered through gauze and a rather complex medium was used, but it remains unclear whether this procedure had any effect on the experimental results.

Although all five fibre sources contained large amounts of dietary fibre, some contaminant compounds were present in significant amounts: for example, protein and starch represented up to approximately $15 \%$ of sugarbeet fibre and pectin respectively. When fermented, proteins lead to a much lower production of SCFA than carbohydrates do (Macfarlane et al. 1988): their role in fermentation was hence neglected. Starch is a normal component of apples, especially in unripened fruits (Gorin et al. 1978), and is commonly present in apple pectin (Kravtchenko et al. 1992). It could have been chemically (Kravtchenko et al. 1992) or enzymically (Pishchiiski \& Lyutskanov, 1978; Kravtchenko et al. 1992) removed to avoid production of SCFA from non-fibre material, but such a treatment can lead to partial destruction of the pectic fraction (Lyutskanov et al. 1974). Little information is available about apple starch; however, Sawai et al. (1978) showed that the X-ray diffraction pattern of starch from unripened apples is close to that of B type starch. As far as we know, this kind of starch is poorly degradable and is not fermented by colonic bacteria (Wyatt \& Horn, 1988). Hence, fermentation of apple starch was neglected. 


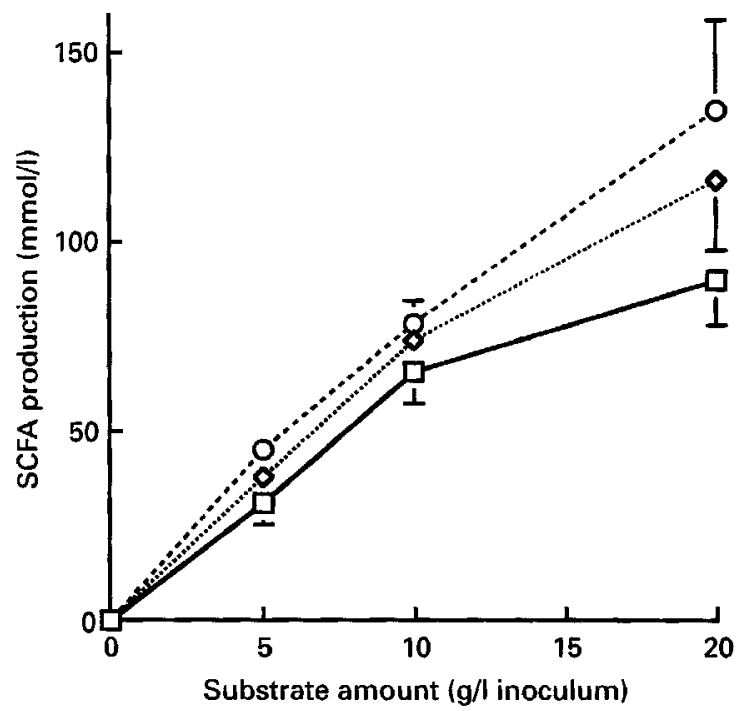

Fig. 6. Influence of the amount of substrate added to the inoculum on short-chain fatty acid (SCFA) production (mmol/1) during the course of in vitro fermentations using human faecal bacteria. Fermentation times were 6 $(-\square-), 10\left(--{ }_{--}\right)$and $24\left(--\mathrm{O}_{--}\right)$h. Values are means for three laboratories, with their standard errors represented by vertical bars.

Table 9. Total short-chain fatty acid (SCFA) production ( $m$ mol/l) and molar proportions of the individual SCFA $(\%)$ produced during in vitro fermentation of the dietary fibre sources by faecal inocula from four different donors

\begin{tabular}{|c|c|c|c|c|c|c|c|c|c|}
\hline & \multirow{2}{*}{$\begin{array}{l}\text { Time } \\
\text { (h) }\end{array}$} & \multicolumn{4}{|c|}{ Donor } & \multirow[b]{2}{*}{ Mean } & \multirow[b]{2}{*}{$\mathrm{SD}_{\mathrm{s}}$} & \multirow[b]{2}{*}{$\mathrm{SD}_{0}$} & \multirow[b]{2}{*}{ LSD } \\
\hline & & A & $\mathbf{B}$ & C & $\mathrm{D}$ & & & & \\
\hline \multirow[t]{3}{*}{ SCFA } & 6 & $52 \cdot 5$ & $28 \cdot 0$ & $40 \cdot 1$ & $32 \cdot 3$ & $38 \cdot 2$ & $7 \cdot 8$ & $12 \cdot 8$ & $24 \cdot 5$ \\
\hline & 10 & $69 \cdot 1$ & 27.9 & $60 \cdot 1$ & $55 \cdot 5$ & $53 \cdot 2$ & 3.9 & $19 \cdot 7$ & 37.0 \\
\hline & 24 & 900 & $73 \cdot 6$ & $89 \cdot 6$ & $74 \cdot 6$ & 82.0 & $9 \cdot 1$ & $19 \cdot 3$ & $36 \cdot 4$ \\
\hline \multirow[t]{3}{*}{ Acetate } & 6 & $51 \cdot 8$ & 54.9 & $49 \cdot 9$ & $58 \cdot 6$ & 53.8 & 3.8 & $8 \cdot 5$ & 16.0 \\
\hline & 10 & $55 \cdot 4$ & $51 \cdot 7$ & 50.7 & $58 \cdot 2$ & $54 \cdot 0$ & 0.7 & $5 \cdot 8$ & 110 \\
\hline & 24 & $53 \cdot 7$ & $49 \cdot 1$ & 51.9 & $59 \cdot 1$ & $53 \cdot 4$ & $3 \cdot 4$ & $4 \cdot 8$ & $10 \cdot 3$ \\
\hline \multirow{3}{*}{ Propionate } & 6 & $23 \cdot 3$ & $16 \cdot 8$ & $35 \cdot 5$ & $33 \cdot 2$ & $27 \cdot 2$ & 8.4 & $4 \cdot 0$ & $7 \cdot 6$ \\
\hline & 10 & $23 \cdot 1$ & $22 \cdot 2$ & $33 \cdot 8$ & 34.4 & $28 \cdot 4$ & $6 \cdot 2$ & $3 \cdot 9$ & $7 \cdot 3$ \\
\hline & 24 & $24 \cdot 8$ & 27.6 & $32 \cdot 7$ & $23 \cdot 0$ & 27.0 & $3 \cdot 0$ & $5 \cdot 0$ & $10 \cdot 7$ \\
\hline \multirow{3}{*}{ Butyrate } & 6 & 24.9 & $28 \cdot 3$ & $14 \cdot 6$ & $8-2$ & 19.0 & $7 \cdot 1$ & $10 \cdot 3$ & $19 \cdot 3$ \\
\hline & 10 & $21 \cdot 4$ & $26 \cdot 1$ & $15 \cdot 5$ & $7 \cdot 4$ & 17.6 & 6.8 & 7.5 & $14 \cdot 2$ \\
\hline & 24 & $21 \cdot 6$ & $23 \cdot 3$ & $15 \cdot 4$ & $6 \cdot 7$ & $16 \cdot 8$ & $5 \cdot 8$ & $8 \cdot 3$ & 17.9 \\
\hline
\end{tabular}

$\mathrm{SD}_{\mathrm{s}}$, standard deviation among subjects; $\mathrm{SD}_{0}$, standard deviation among occasions; LSD, least significant difference $(P<0.05)$.

The five fibre sources were selected to represent the maximal range of potential fermentabilities likely to be encountered in in vitro experiments. The mean degradation rates determined during the ring test are in good agreement with previously published results for cellulose (Ehle et al. 1982; Jeraci \& Horvath, 1989), pectin (Titgemeyer et al. 1991), sugarbeet fibre (Titgemeyer et al. 1991; Guillon et al. 1992; Salvador et al. 1993), maize bran (Titgemeyer et al. 1991) and soyabean fibre (Titgemeyer et al. 1991). The low degradation of cellulose (high crystallinity) and high breakdown of pectin, soyabean fibre 
Table 10. Analysis of variance of the adaptation experiment*

\begin{tabular}{|c|c|c|c|c|c|c|}
\hline $\begin{array}{l}\text { Incubation } \\
\text { time (h) }\end{array}$ & Factors & $\mathrm{df}$ & $\begin{array}{c}\text { Total } \\
\text { squares }\end{array}$ & $\begin{array}{c}\text { Mean } \\
\text { squares }\end{array}$ & $F$ & $P$ \\
\hline \multirow[t]{4}{*}{6} & Adaptation & 2 & $10 \cdot 49$ & $5 \cdot 24$ & $0 \cdot 01$ & 0.9856 \\
\hline & Substrate & 2 & $4873 \cdot 76$ & 2436.88 & $6 \cdot 75$ & 0.0162 \\
\hline & Interaction & 4 & $254 \cdot 69$ & 63.67 & 0.18 & 0.9449 \\
\hline & Residual error & 9 & $3248 \cdot 15$ & 360.91 & & \\
\hline \multirow[t]{4}{*}{10} & Adaptation & 2 & $19 \cdot 7$ & $9 \cdot 85$ & 0.02 & 0.9809 \\
\hline & Substrate & 2 & $3172 \cdot 27$ & $1586 \cdot 14$ & $3 \cdot 1$ & 0.0943 \\
\hline & Interaction & 4 & $140 \cdot 12$ & 35.03 & 0.07 & 0.9899 \\
\hline & Residual error & 9 & 4597.62 & $510 \cdot 85$ & & \\
\hline \multirow[t]{4}{*}{24} & Adaptation & 2 & 106.05 & $53 \cdot 03$ & 0.29 & 0.7561 \\
\hline & Substrate & 2 & $1074 \cdot 92$ & $537 \cdot 46$ & 2.92 & 0.1051 \\
\hline & Interaction & 4 & $176 \cdot 3$ & $44 \cdot 07$ & 0.24 & 0.9088 \\
\hline & Residual error & 9 & $1654 \cdot 54$ & $183 \cdot 84$ & & \\
\hline
\end{tabular}

* For details of the adaptation experiment, see p. 307.

Table 11. Values for $\mathrm{pH}$, total short-chain fatty acid (SCFA) production (mmol/l) and molar proportions of the individual SCFA $(\%)$ during in vitro fermentation of pectin and soyabean fibre by faecal inocula from rats and humans

(Mean values and standard deviations for two laboratories)

\begin{tabular}{|c|c|c|c|c|c|c|c|c|c|c|c|c|}
\hline & & \multirow{2}{*}{$\begin{array}{l}\text { Time } \\
\text { (h) }\end{array}$} & \multicolumn{2}{|c|}{$\mathrm{pH}$} & \multicolumn{2}{|c|}{ SCFA } & \multicolumn{2}{|c|}{ Acetate } & \multicolumn{2}{|c|}{ Propionate } & \multicolumn{2}{|c|}{ Butyrate } \\
\hline & & & Mean & SD & Mean & SD & Mean & SD & Mean & SD & Mean & SD \\
\hline \multirow[t]{6}{*}{ Pectin } & Rat & 0 & 6.91 & 0.36 & - & - & - & - & - & - & 一 & - \\
\hline & & 6 & $6 \cdot 13$ & 0.99 & $63 \cdot 4$ & $3 \cdot 3$ & $78 \cdot 2$ & $3 \cdot 8$ & $10 \cdot 9$ & 0.9 & $11 \cdot 0$ & $2 \cdot 6$ \\
\hline & & 24 & $6 \cdot 57$ & 0.40 & $60 \cdot 9$ & 13.6 & 74.9 & $4 \cdot 8$ & $11 \cdot 8$ & 0.6 & $13 \cdot 4$ & 3.9 \\
\hline & Human & 0 & 6.83 & 0.19 & - & - & - & - & - & - & - & - \\
\hline & & 6 & 6.24 & 0.22 & 65.4 & $2 \cdot 7$ & 77.0 & 1.5 & $10 \cdot 1$ & 1.9 & 13.0 & 1.2 \\
\hline & & 24 & 6.28 & $0 \cdot 10$ & $70 \cdot 2$ & $7 \cdot 2$ & $71 \cdot 8$ & 0.5 & $12 \cdot 1$ & $2 \cdot 1$ & $16 \cdot 2$ & 2.6 \\
\hline \multirow{6}{*}{$\begin{array}{l}\text { Soyabean } \\
\text { fibre }\end{array}$} & Rat & 0 & 6.97 & 0.45 & - & - & 一 & - & - & - & - & 一 \\
\hline & & 6 & 5.98 & 0.31 & $49 \cdot 0$ & $14 \cdot 0$ & $63 \cdot 9$ & $2 \cdot 6$ & $21 \cdot 0$ & 0.9 & $15 \cdot 1$ & $3 \cdot 4$ \\
\hline & & 24 & $6 \cdot 37$ & 0.25 & $65 \cdot 3$ & 0.6 & $62 \cdot 0$ & $5 \cdot 0$ & $21 \cdot 5$ & 0.6 & $16 \cdot 6$ & $4 \cdot 3$ \\
\hline & Human & 0 & 6.94 & 0.34 & - & - & - & - & - & - & - & - \\
\hline & & 6 & 6.26 & 0.49 & $64 \cdot 1$ & $32 \cdot 5$ & $64 \cdot 4$ & $4 \cdot 5$ & $19 \cdot 8$ & $3 \cdot 6$ & 15.9 & 0.9 \\
\hline & & 24 & $6 \cdot 54$ & 0.37 & $87 \cdot 7$ & $28 \cdot 0$ & 66.9 & 6.9 & $19 \cdot 8$ & $5 \cdot 2$ & $13 \cdot 4$ & $1 \cdot 6$ \\
\hline
\end{tabular}

and sugarbeet fibre (high soluble-fibre content and pectin-rich primary cell walls) were as expected. The low rates of breakdown for maize bran were more surprising since this substrate has a very low lignin content. The limiting factor for wheat-bran degradability is thought to be the presence of branched arabinoxylans (Salvador et al. 1993). The fact that such highly branched compounds are found in maize bran, in which they are associated with high levels of phenolic acids (Saulnier et al. 1993), may account for the low fermentability of this fibre.

$\mathrm{pH}$ variations, when indicative of SCFA production, can be used as an index of fibre fermentation (Guillon et al. 1992). Surprisingly, even though soyabean fibre was highly fermented, $\mathrm{pH}$ during the ring test varied only slightly. Since $\mathrm{NH}_{3}$ can be produced during fermentation of nitrogenous compounds (Vince et al. 1990), this may have limited the $\mathrm{pH}$ decrease. Although $\mathrm{NH}_{3}$ concentrations were not measured, it is unlikely that this factor 
could account for the unusual behaviour of this fibre. The amounts and solubilities of nitrogenous compounds were not very different from those measured in the other fibre sources, especially pectin, which exhibited a dramatic $\mathrm{pH}$ decrease. These results suggest that $\mathrm{pH}$ on its own should not be used as an index of fermentability.

Carbohydrate determinations in complex media led to some problems. Since bacteria contain some carbohydrates (Stephen \& Cummings, 1980) which would be measured by the colorimetric procedure used in this ring test, it was important to subtract the blank value representing the carbohydrate in the inoculum at each fermentation time. Second, it was observed that faecal slurries interfered with the colorimetric reaction. Amounts of carbohydrate, when determined after addition to the inoculum, were always lower than the actual values. This problem was corrected by performing all determinations, including time 0 , in slurries. However, this interference appeared to be greater with substrates such as pectin or soyabean fibre. Although care was taken to stop fermentation as soon as substrates were added in the corresponding blanks, rapid breakdown could have occurred with these highly degradable fibres. In so far as these substrates were totally degraded at the end of fermentation, this problem should only have decreased the degradability measured during the first fermentation periods. However, this may have affected the overall fermentability estimation of substrates with intermediary degradability, such as sugarbeet fibre.

With non-fermentable substrates (cellulose, maize bran), carbohydrate determinations gave some unexpected values. Problems in the quantification of crystalline cellulose often occurred. Due to its crystalline structure, this substrate resists hydrolysis (Hoebler et al. 1989). The occasional unexpectedly high figures for cellulose degradation suggest that the carbohydrate was hydrolysed less readily in the inoculum than in its native form.

On the whole, carbohydrate determinations were not sufficiently accurate. This imprecision was due at least in part to the high values sometimes observed with blank samples. Because the method was based on different measurements, its precision was inversely related to the relative importance of blank values. One solution could be to use more diluted inocula (McBurney \& Thompson, 1987, 1989; McBurney et al. 1988; Adiotomre et al. 1990). In this case, however, the incubations would be completely nonphysiological. With respect to the non-specific carbohydrate determination methods used, it would appear that a compromise needs to be found between the high fermentative activity of an inoculum obtained with low dilutions of faeces, and the low interferences obtained with high dilutions of sample. Though specific methods involving chromatographic determination of carbohydrates are more complex and thus less suited to routine use, they can provide accurate results, even with relatively concentrated inoculum (Guillon et al. 1992).

A very close relationship was found between NSP loss and SCFA production. Degradation has been reported for only one dietary fibre source (laminarin from seaweed) when associated SCFA production was low (Michel et al. 1995). In our experiments, the rate of conversion of hydrolysed NSP into SCFA was constant, irrespective of carbohydrate origin. This has been reported previously (Salvador et al. 1993). As SCFA determination is precise and easy to perform, this variable, which is predictive of almost all variations in substrate degradation $\left(r^{2} 0.98\right)$, can be used in most experiments as an index of fibre degradation. However, it must be emphasized for future studies that the molar yield of SCFA from carbohydrate differs according to the particular end-products produced. In this respect, some discrepancies between the sum of SCFA produced and the NSP fermented could be observed when very different SCFA ratios are observed.

SCFA profiles calculated for substrates exhibiting significant degradation (pectin, soyabean fibre, sugarbeet fibre) were in close agreement with previous findings. For all 
substrates, acetate was the major SCFA produced, and acetate and propionate were the two SCFA showing variability between different substrates. The highest acetate production was observed with pectin, as reported previously (Goodlad \& Mathers, 1988; Titgemeyer et al. 1991). This may be related to the fermentation of uronic acids to acetate (Salvador et al. 1993). Conversely, the fact that pectin fermentation resulted in a very low proportion of propionic acid is in close agreement with previous findings in vivo (Englyst et al. 1987; Mathers \& Finlayson, 1989) and in vitro (Goodlad \& Mathers, 1988) and confirms that uronic acid metabolism is not involved in production of propionate (Salvador et al. 1993). Soyabean fibre fermentation was characterized by relatively high proportions of propionate, which is concordant with the findings of Levrat et al. (1991). There were no differences between the substrates with respect to butyrate which contributed between about 13 and $17 \%$ of SCFA products. These results contrast with those obtained when a continuous in vitro fermenter was used, which indicated very low butyrate production with pectin (Edwards et al. 1985). As significant amounts of butyrate have been quantified in vivo, it would appear that in vitro batch systems reproduce colonic fermentations at least as well as do continuous fermenters.

The procedure for the ring test gave results in good agreement with published data. Nonetheless, the use of the same procedure and substrates by laboratories accustomed to conducting such in vitro experiments led to differences concerning the rate of substrate degradation, the amount of SCFA produced and the relative proportion of each major SCFA. As the main potential source of variation was presumably the activities of bacteria in the faeces used for the preparation of inocula, a series of experiments analysing this variability was carried out. Interdonor variability was not significant. This is in close agreement with previous results of Mortensen et al. (1991) who found the intra- and interindividual variations were of the same magnitude but disagrees with the findings of McBurney \& Thompson (1987). This could have been due to our use of replications on different occasions, whereas McBurney \& Thompson (1987) only used duplicates made with the same faeces, which are not indicative of intradonor variability. Our experiment showed that intradonor variability was on the whole in the same range as interdonor variability. It would thus seem important to replicate experiments as well as donors.

Although large donor-related variations in activity were found between laboratories in the same country, and could also have occurred between countries because of eating habits, our experiments indicate that donor adaptation to fibre ingestion was not an influential factor. Such an adaptation effect was recently pointed out (Michel et al. 1996) concerning a very unusual fibre from seaweed. However, in this case, adaptation was achieved in a very short time (about $6 \mathrm{~h}$ ), did not make products fermentable which were previously unfermentable, and changed the rate and not the extent of degradation of already fermentable fibre without altering the profile of major SCFA. For common fibres at least, the effect of the donor diet probably cannot account for interlaboratory differences. Hence, it does not seem necessary to adapt volunteers to a fibre when fermentation is to be studied in vitro.

Experiments conducted with rat inocula compared with human inocula confirmed these conclusions. Within a laboratory there was no difference between fermentation conducted with inocula made from caecal contents of the adapted rat, or with those made from unadapted human donors, as previously noted by Nyman et al. (1986). This seems to confirm that the nature of fibre during fermentation is more important than the source of the flora. Nonetheless, large differences were observed between laboratories. Since donor variability cannot account for these variations, the cause remains unclear.

Interlaboratory differences concerned the extent of fermentation in particular. These differences did not apply to highly fermentable fibres which were always extensively 


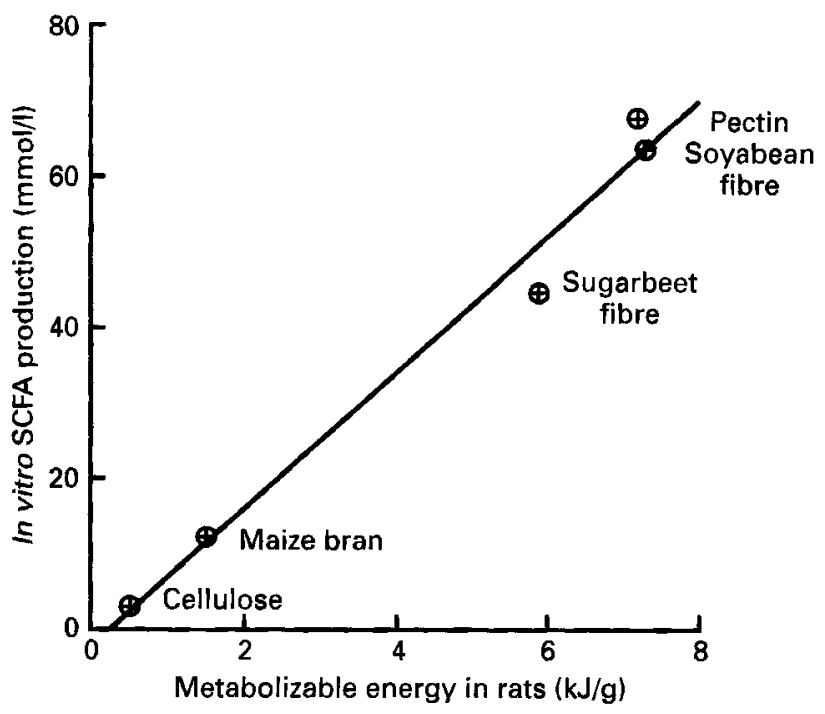

Fig. 7. Relationship between the metabolizable energy of five different fibre sources (determined in rats; Livesey et al. 1995) and production of short-chain fatty acids (SCFA) from the same fibre sources in vitro. The line is described by the equation $y=9 \cdot 00 x-2 \cdot 12(r 0.991)$.

fermented, or to unfermentable products which were never broken down, but to fibres with intermediate fermentability such as sugarbeet fibre, which are highly degraded with highactivity inocula or poorly degraded with low-activity inocula. In so far as in vitro experiments are used to study the intrinsic degradability of fibre, they should be undertaken with excess degrading activity in the faecal inocula. Experiments concerned with the influence of substrate amounts demonstrated that inoculum activity was the limiting factor when substrate was added at levels higher than $10 \mathrm{~g} / \mathrm{l}$. During the ring-test experiment some laboratories may have worked with limited-activity inocula, though this question remains to be answered. A potential solution could be reached either by lowering faeces dilution or be decreasing the substrate amount from 10 to $5 \mathrm{~g} / \mathrm{l}$. In both cases, this would increase background for carbohydrate determination and indicate the need for a more specific form of carbohydrate determination than colorimetric methods.

Another difference between laboratories concerned the molar ratios of SCFA produced during fermentation. Once again, substrate ranking was the same for all laboratories. On the whole, it would appear to be difficult to obtain absolute data either for the fibre degradation rate or SCFA molar ratios. However, when only relative degradation data are needed, the methodology employed here allows accurate ranking of fibre degradability. Because some variability cannot be avoided, it would seem preferable to carry out experiments with well-referenced standard fibres. Moreover, future use of such a method should take into account the ISO Standard 5725 precision of test. Since the ranking of fibre degradation or the SCFA ratio was not modified by the length of the in vitro fermentation period, and in so far as only relative figures are needed, future studies could be conducted over shorter times than $24 \mathrm{~h}$. However, short-term fermentations reflect the rate of fermentation, whereas extended fermentations indicate the extent of fermentation: in this respect, short and long incubations are necessary.

The same dietary fibre sources as those used here were previously tested in vivo in rats (Livesey et al. 1995). There was a very close relationship between in vitro $(y)$ and in vivo $(x)$ fibre degradation $(y=0.728 x-2.786, r 0.986)$ which indicates that there was a very close 
agreement between data for both modes of measurement. NSP degradation was lower in vitro: we do not know how long fibres stayed in the colon of rats; if in vitro fermentation times had been extended to 30 or $36 \mathrm{~h}$, in vitro fermentation figures would have been closer to those observed in vivo. This comparison validates the methodology tested here in vitro, which is accurate when rapid classification of fibre degradation by colonic bacteria is required. The relationship between in vitro fibre degradation and in vivo metabolizable energy of fibre sources is shown in Fig. 7. This relationship clearly indicates that the in vitro methodology which was tested during this experiment is accurate for a rapid determination of energy content of dietary fibre.

\section{CONCLUSION}

Many previous studies have used in vitro batch fermenters to study dietary fermentation by intestinal bacteria. Until now, none of these methodologies has been validated, which led us to undertake this first interlaboratory study. In most cases, very similar results were found during the ring test, even though some interlaboratory differences of unknown origin remain. The methodology used allows rapid, accurate study of dietary fibre fermentation, and the experimental results show a close relationship between colonic NSP degradation and SCFA production. Moreover, in vitro SCFA production was highly correlated with fibre energy value in rats. On the whole, the in vitro methodology tested allows rapid prediction of the energy content of fibre.

This work was carried out with the skilful assistance of $\mathrm{C}$. Bonnet, A. David and S. Guéneau in Nantes, France; N. Quispé, D. Smith and S. Livens in Carshalton; and J. Christiansen, B. Petersen and A. B. Larsen in Copenhagen, Denmark. The authors are grateful to the International Life Science Institute-ILSI Europe for financial support and assistance with coordination. They are also thankful for the expert assistance of $\mathrm{Dr}$ U. Priebe of ILSI Europe, Dr G. Livesey of the Institute of Food Research (Norwich), J-M. Antoine of Danone (Paris, France) and T. F. Schweizer of Nestlé (Vers-Chez-LesBlancs, Switzerland).

\section{REFERENCES}

Adiotomre, J., Eastwood, M. A., Edwards, C. A. \& Brydon, W. (1990). Dietary fibre: in vitro methods that anticipate nutrition and metabolic activity in humans. American Journal of Clinical Nutrition 52, 128-134.

Barry, J.-L., Chourot, J.-M., Bonnet, C., Kozlowski, F. \& David, A. (1989). In vitro fermentation of neutral monosaccharides by ruminal and human fecal microflora. Acta Veterinaria Scandinavica 86, Suppl., 93-95.

Cherbut, C. (1995). Effects of short chain fatty acids on gastro-intestinal motility. In Physiological and Clinical Aspects of Short Chain Fatty Acid Metabolism, pp. 191-207 [J. H. Cummings, T. Sakata and J. L. Rombaud, editors]. Cambridge: Cambridge University Press.

Cummings, J. H., Pomare, E. W., Branch, W. J., Naylor, C. P. E. \& Macfarlane, G. T. (1987). Short chain fatty acids in human large intestine, portal, hepatic and venous blood. Gut 28, 1221-1227.

Daniéli, P. (1975). Théorie et méthodes statistiques. Vol II: les méthodes de l'interférence statistique, pp. 121-122. Gembloux, Belgium: Les presses agronomiques de Gembloux.

Durand, M., Dumay, C., Beaumatin, P. \& Morel, M.-T. (1988). Use of the rumen simulation technique (RUSITEC) to compare microbial digestion of various by-products. Animal Feed Science and Technology 21, 197-204.

Edwards, C. A., Duerden, B. I. \& Read, N. W. (1985). Metabolism of mixed human colonic bacteria in a continuous culture mimicking the human cecal contents. Gastroenterology 88, 1903-1909.

Ehle, F. R., Jeraci, J. L., Robertson, J. B. \& Van Soest, P. J. (1982). The influence of dietary fibre on digestibility, rate of passage and gastrointestinal fermentations in pigs. Journal of Animal Science 55, 1071-1080.

Englyst, H. N. \& Hudson, G. J. (1987). Colorimetric method for routine measurement of dietary fibre as nonstarch polysaccharides. A comparison with gas-liquid chromatography. Food Chemistry 24, 63-76.

Englyst, H. N. \& Cummings, J. H. (1988). An improved method for the measurement of dietary fibre as the nonstarch polysaccharides in plant foods. Journal of the Association of Official Analytical Chemists 71, 808-814.

Englyst, H. N., Hay, S. \& Macfarlane, G. T. (1987). Polysaccharide breakdown by mixed populations of human faecal bacteria. FEMS Microbiology Ecology 95, 163-171. 
Faisant, N., Planchot, V., Kozlowski, F., Pacouret, M.-P., Colonna, P. \& Champ, M. (1995). Resistant starch determination adapted to products containing high levels of resistant starch. Science des Aliments 15, 83-89.

Fidgor, S. K. \& Bianchine, J. R. (1983). Caloric utilization and disposition of $\left[{ }^{14}\right.$ C]polydextrose in man. Journal of Agricultural and Food Chemistry 31, 389-393.

Flick, J. A. \& Perman, J. A. (1989). Nonabsorbed carbohydrate: effect on fecal pH in methane-excreting and nonexcreting individuals. American Journal of Clinical Nutrition 49, 1252-1257.

Gibson, G. R., Cummings, J. H. \& Macfarlane, G. T. (1988). Use of a three-stage continuous culture system to study the effect of mucin on dissimilatory sulfate reduction and methanogenesis by mixed populations of human gut bacteria. Applied and Environmental Microbiology 54, 2750-2755

Goodlad, J. S. \& Mathers, J. C. (1988). Effects of food carbohydrates on large intestinal fermentation in vitro. Proceedings of the Nutrition Society 47, 176A.

Gorin, N., Bonisolli, F., Heidema, F. T., Klop, W. \& Williams, A. A. (1978). Changes in starch content and amylase zymograms during storage of Golden delicious and Cox's orange pippin apples. Zeischtrift für Lebensmittel-Undersuchung und-Forschung 166, 157-161.

Guillon, F., Barry, J.-L. \& Thibault, J.-F. (1992). Effect of autoclaving sugar-beet fibre on its physico-chemical properties and its in-vitro degradation by human faecal flora. Journal of the Science of Food and Agriculture 60 , 69-79.

Hoebler, C., Barry, J.-L., David, A. \& Delort-Laval, J. (1989). Rapid acid hydrolysis of plant cell wall polysaccharides and simplified quantitative determination of their neutral monosaccharides by gas-liquid chromatography. Journal of Agricultural and Food Chemistry 37, 360-367.

Holdeman, L. V., Cato, E. P. \& Moore, W. E. C. (eds) (1977). Anaerobic Laboratory Manual, 4th ed. Blacksburg, VA: VPI Anaerobe Laboratory.

Jeraci, J. L. \& Horvath, P. J. (1989). In vitro fermentation of dietary fiber by human fecal organisms. Animal Feed Science and Technology 23, 121-140.

Jouany, J.-P. (1982). Dosage des acides gras volatils (AGV) et des alcools dans les contenus digestifs, les jus d'ensilage, les cultures bactériennes et les contenus de fermenteurs anaérobies (Volatile fatty acid and alcohol determination in digestive contents, silage juices, bacterial cultures and anaerobic fermenter contents). Science des Aliments 2, 131-144.

Kravtchenko, T. P., Voragen, A. G. J. \& Pilnik, W. (1992). Analytical comparison of three industrial pectin preparations. Carbohydrate Polymers 18, 17-25.

Levrat, M. A., Behr, S. R., Rémésy, C. \& Demigné, C. (1991). Effect of soybean fiber on cecal digestion in rats previously adapted to a fiber-free diet. Journal of Nutrition 121, 672-678.

Livesey, G. (1990). Energy value of unavailable carbohydrates and diets. An inquiry and analysis. American Journal of Clinical Nutrition 51, 617-637.

Livesey, G., Smith, T., Eggum, B. O., Tetens, I. H., Nyman, M., Roberfroid, M., Delzenne, N., Schweizer, T. F. \& Decombaz, J. (1995). Determination of digestible energy values and fermentabilities of dietary fibre supplements: a European interlaboratory study in vivo. British Journal of Nutrition 74, $289-302$.

Lyutskanov, N., Pishtiiskii, I. \& Krachanov, K. (1974). Enzymic purification of apple pectin. In Pervyi simposium Proizvodstvo $i$ primeneie fermentnykh preparatov $v$ pishchevoi promyshlennosti izhivotnovadstve, 726-727 [G. Klyushnik, V. Rzhendovski, E. Rembovski, N. Nestorov, A. Grozdanov, P. Konishev, G. Uzunov, S. Chara, T. Angelov, I. Grigorov and M. Angelova, editors]. USSR: Koordinatsionnyi Tseutr po Problem.

McBurney, M. I., Horvath, P. J., Jeraci, J. L. \& Van Soest, P. J. (1985). Effect of in vitro fermentation using human faecal inoculum on the water-holding capacity of dietary fibre. British Journal of Nutrition 53, 17-24.

McBurney, M. I. \& Thompson, L. U. (1987). Effect of faecal inoculum on in vitro fermentation variables. British Journal of Nutrition 58, 233-243.

McBurney, M. I. \& Thompson, L. U. (1989). Effect of human faecal donor on in vitro fermentation variables. Scandinavian Journal of Nutrition 24, 359-367.

McBurney, M. I., Thompson, L. U., Cuff, D. J. \& Jenkins, D. J. A. (1988). Comparison of ileal effluents, dietary fibers, and whole foods in predicting the physiological importance of colonic fermentation. American Journal of Gastroenterology 83, 536-540.

Macfarlane, G. T., Allison, C., Gibson, S. A. W. \& Cummings, J. H. (1988). Contribution of the microfiora to proteolysis in the human large intestine. Journal of Applied Bacteriology 64, 37-46.

Mallett, A. K., Bearne, C. A. \& Rowland, I. R. (1983). Metabolic activity and enzyme induction in rat fecal microflora maintained in continuous culture. Applied and Environmental Microbiology 46, 591-595.

Mathers, J. C., Fernandez, F., Hill, M. J., McCarthy, P. T., Shearer, M. J. \& Oxley, A. (1990). Dietary modification of potential vitamin $\mathrm{K}$ supply from enteric bacterial menaquinones in rats. British Journal of Nutrition 63, 639-652.

Mathers, J. C. \& Finlayson, H. J. (1989). Manipulation of rat caecal metabolism by incubating Avoparin and pectin in the diet. Proceedings of the Nutrition Society 48, 139A.

Michel, C., Lahaye, M., Bonnet, C., Mabeau, S. \& Barry, J.-L. (1996). In vitro fermentation by human faecal bacteria of total and purified dietary fibres from brown seaweeds. British Journal of Nutrition (In the Press).

Miller, T. M. \& Wolin, M. J. (1981). Fermentation by the large intestine microbial community in an in vitro semicontinuous culture system. Applied and Environmental Microbiology 42, 400-407. 
Mortensen, P. B., Heghøj, J., Rannen, T., Rasmussen, H. S. \& Holtug, L. (1989). Short-chain fatty acids in bowel contents after intestinal surgery. Gastroenterology 97, 1090-1096.

Mortensen, P. B., Holtug, K. \& Rasmussen, H. S. (1988). Short-chain fatty acid production from mono- and disaccharides in a fecal incubation system: implications for colonic fermentation of dietary fiber in humans. Journal of Nutrition 118, 321-325.

Mortensen, P. B., Hove, H., Clausen, M. R. \& Holtug, K. (1991). Fermentation to short-chain fatty acids and lactate in human faecal batch cultures. Scandinavian Journal of Gastroenterology 26, 1285-1294.

Mortensen, P. B. \& Nordgaard-Andersen, I. (1993). The dependence of the in vitro fermentation of dietary fibre to short-chain fatty acids on the contents of soluble non-starch polysaccharides. Scandinavian Journal of Gastroenterology 28, 418-422.

Nyman, M., Asp, N. G., Cummings, J. H. \& Wiggins, H. (1986). Fermentation of dietary fibre in the intestinal tract: comparison between man and rat. British Journal of Nutrition 55, 487-496.

Patil, D. H., Westaby, D., Mahida, Y. R., Palmer, K. R., Rees, R., Clark, M. L., Dawson, A. M. \& Silk, D. B. A. (1987). Comparative modes of action of lactitol and lactulose in the treatment of hepatic encephalopathy. Gut 28, 255-259.

Perman, J. A. \& Modler, S. (1982). Glycoproteins as substrates for production of hydrogen and methane by colonic bacterial flora. Gastroenterology 83, 388-393.

Pishchiiski, I. \& Lyutskanov, N. (1978). Improving the purity of apple pectin by use of amylolytic preparations. Nauchni-Trudovev-Vissh-Institut-po-Khranitelna-i-Vkusova-Promyshlennost 25, 347-350.

Prosky, L., Asp, N. G., Schweizer, T., De Vries, J. W. \& Furda, I. (1992). Determination of insoluble and soluble dietary fiber in foods and food products: collaborative study. Journal of the Association of Official Analytical Chemists 75, 360-367.

Rasmussen, H. S., Holtug, K., Andersen, J. R., Krag, E. \& Mortensen, P. B. (1987). The influence of ispaghula husk and lactulose on the in vivo and the in vitro production capacity of short-chain fatty acids in humans Scandinavian Journal of Gastroenterology 22, 406-410.

Roediger, W. E. W. (1982). Utilisation of nutrients by isolated epithelial cells of the rat colon. Gastroenterology 83, 424429

Salvador, V., Cherbut, C., Barry, J.-L., Bertrand, D., Bonnet, C. \& Delort-Laval, J. (1993). Sugar composition of dietary fibre and short-chain fatty acid production during in vitro fermentation by human bacteria. British Journal of Nutrition 70, 189-197.

Saulnier, L., Mestres, C., Doublier, J.-L., Roger, P. \& Thibault, J.-F. (1993). Studies of polysaccharides solubilized during alkaline cooking of maize kernels. Journal of Cereal Science 17, 267-276.

Sawai, K., Sandonsuge, Y., Izuiyama, Y. \& Okagawa, Y. (1978). Biochemical studies on apple fruits. III. Some physical properties of starch granules observed through an X-ray diffractometer and a microscope. Bulletin of the Faculty of Agriculture, Hirosaki University 29, 1-9.

Schooley, D. L., Kubiak, F. M. \& Evans, J. V. (1985). Capillary gas chromatographic analysis of volatile and nonvolatile organic acids from biological samples as the t-butylmethylsilyl derivatives. Journal of Chromatographic Science 23, 385-390.

Slade, A. P., Wyatt, G. M., Bayliss, C. E. \& Waites, W. M. (1987). Comparison of populations of human faecal bacteria before and after in vitro incubation with plant cell wall substrates. Journal of Applied Bacteriology 62, 231-240.

Stephen, A. M. \& Cummings, J. H. (1980). The microbial contribution to human faecal mass. Journal of Medical Microbiology 13, 45-56.

Stevens, J. H., Selvendran, R. R., Bayliss, C. E. \& Turner, R. (1988). Degradation of cell wall material of apple and wheat bran by faecal bacteria in vitro. Journal of the Science of Food and Agriculture 44, 151-166.

Titgemeyer, E. C., Bourquin, L. D., Fahey, G. C. \& Garleb, K. A. (1991). Fermentability of various fiber sources by human fecal bacteria in vitro. American Journal of Clinical Nutrition 53, 1418-1424.

Tomlin, J. \& Read, N. W. (1988). The relation between bacterial degradation of viscous polysaccharides and stool output in human beings. British Journal of Nutrition 60, 467-475.

Tomlin, J., Read, N. W., Edwards, C. A. \& Duerden, B. I. (1986). The degradation of guar gum by faecal incubation system. British Journal of Nutrition 55, 481-486.

Vérité, R. \& Demarquilly, C. (1978), Qualité des matières azotées des aliments pour ruminants (Quality of crude proteins in feeds for ruminants). In La Vache Laitière, pp, 143-157. Versailles: INRA Publications.

Vince, A. J., McNeil, N. I., Wager, J. D. \& Wrong, O. M. (1990). The effect of lactulose, pectin, arabinogalactan and cellulose on the production of organic acids and metabolism of ammonia by intestinal bacteria in a faecal incubation system. British Journal of Nutrition 63, 17-26.

Wolever, T. M. S., Spadafora, P. \& Ashuis, H. (1992). Interaction between colonic acetate and propionate in humans. American Journal of Clinical Nutrition 53, 681-687.

Wyatt, G. M. \& Horn, N. (1988), Fermentation of resistant starches by human and rat intestinal bacteria. Journal of the Science of Food and Agriculture 44, 281-288. 